\title{
Stormwater Biofilter Media Performance Updates for WinSLAMM: Data Summary for Unit Process Components, Example Calculations and Model Use
}

\author{
R. Pitt, ${ }^{1}$ S. E. Clark, ${ }^{2}$ R. Sileshi, ${ }^{3}$ and J. Voorhees ${ }^{4}$ \\ ${ }^{1}$ University of Alabama, Tuscaloosa, Alabama; ${ }^{2}$ Penn State-Harrisburg, Middletown, Pennsylvania; ${ }^{3}$ University of North Georgia, Gainesville, \\ Georgia; ${ }^{4}$ PV and Assoc., Madison, Wisconsin.
}

\begin{abstract}
This paper focuses on specific information needed to model various aspects of the pollutant retention processes in stormwater biofilters. Updates currently being incorporated in WinSLAMM (Source Loading and Management Model) are building on expanded data from laboratory and field research mostly conducted by Pitt's research group at the University of Alabama, Tuscaloosa, by Dr. Shirley Clark's research group at Penn State-Harrisburg, and the Wisconsin Department of Natural Resources and the U.S. Geological Survey (DNR/USGS). These processes and data can be used in manual calculations or other models. Extensive summaries of these data sources and associated statistical analyses, plus additional references, are included in an online white paper available at the PV \& Assoc. website. These tests were conducted to provide the details needed for modeling the performance of biofilters, specifically focusing on: methods to predict treatment flow rates through the media; particulate and associated particulate bound pollutant retention for several particle sizes; maintenance requirements due to sediment clogging and pollutant breakthrough; and retention of filterable pollutants. This multiyear research program also examined issues not commonly described in the biofilter performance literature, such as failure due to excessive salt loadings on media having large amounts of fines, problems associated with compaction of the media, and leaching of previously captured material from the media.

This paper consolidates the information from many prior research projects and dissertations and illustrates how these data can be used together for calculating the benefits of stormwater biofilter systems. This paper summarizes the data and the major calculation components to determine biofilter performance. This is followed by a numeric example using these data along with a description of how WinSLAMM describes a biofilter installation and an example development of a production function to assist in the design and evaluation of biofilter options.
\end{abstract}

\section{Introduction}

This paper describes the data and calculations that are being used to update the biofilter performance calculations in WinSLAMM. The literature and online resources describe many biofilters (with underdrains) and bioinfiltration (usually without underdrains, with most of the stormwater treatment associated with infiltration) performance studies. This paper does not include a comprehensive review of these data, as it focuses on the specific information needed to model the various parts of the pollutant retention processes. Most of the data supporting the WinSLAMM model enhancements are from several long term laboratory and field studies:

- Clark's master's thesis and dissertation research using laboratory and pilot scale field testing of different media (Clark 1996, 2000; Clark and Pitt 1999);
- Pitt and Clark's research for The Boeing Company to develop biofilter media mixtures suitable for a wide range of pollutants at an industrial site being restored to open space use (Pitt and Clark 2010), along with full scale multiyear testing of biofilters at this location (Pitt et al. 2021a, 2021b); and

- Sileshi's dissertation on soil and sand media for biofilter treatment flow rates, underdrain design, and retention of particulate sizes (Sileshi 2013).

In addition, several full scale biofilter monitoring projects also contain information and data useful for this summary. Wisconsin DNR and USGS have been monitoring test biofilters to compare the performance of various media mixtures (Bannerman, personal communication). The Kansas City Demonstration Project of Green Infrastructure in Areas served by Combined Sewers

Pitt, R., S. E. Clark, R. Sileshi and J. Voorhees. 2021. "Stormwater Biofilter Media Performance Updates for WinSLAMM: Data Summary for Unit Process Components, Example Calculations and Model Use." Journal of Water Management Modeling 29: C477. https://doi.org/10.14796/JWMM.C477

(c) CHI 2021. www.chijournal.org ISSN 2292-6062. 
(Pitt et al. 2014) included monitoring of many biofilters throughout a large area and examined their benefit at a large scale. Pitt and Talebi (2012) monitored changes in stormwater pollutant concentrations during dry well performance studies as the stormwater passed through underlying soils. Pitt et al. (1999) also conducted monitoring at compost-amended test sites to determine the removal benefits of these soil mixtures.

A comprehensive overview of the performance of biofilters and other stormwater controls is given by the International BMP Database. Unfortunately, few of these studies include detailed data concerning the partitioning of the particulates and pollutants by particle size and by total and filtered forms. In addition, rate kinetics associated with contact times, clogging by particulates, and retention capacity of the media for the wide variety of pollutants of interest are also needed for modeling. This information is needed when modeling the expected behavior of these systems, which rely on a wide range of media for stormwater quality improvements. In addition, the selection of which media (and combinations) to meet desired treatment objectives is also elusive. Clark and Pitt (2012) wrote a summary on targeting treatment technologies (such as media selection) with specific objectives. The use of a comprehensive model that addresses these many issues enables comparisons of alternative biofilter designs.

WinSLAMM, the Source Loading and Management Model, is an urban stormwater model that can be used for single urban lots to complex urban catchments. WinSLAMM is based on field monitoring observations covering a wide range of scales with unique hydrologic and pollutant related components that focus on urban systems. It is mainly used as a planning tool to assess both stormwater and pollutant runoff production and the capability of many stormwater control strategies to reduce stormwater discharges from urban sources (Pitt and Voorhees 2002). Several presentations and papers associated with the annual urban water modeling conferences and the Journal of Water Management Modeling have described WinSLAMM and its attributes (including Avila et al. 2008; Avila and Pitt 2009; Myllyoja et al. 2001; Pitt 1998, 1999; Pitt and Lantrip 2000; Pitt and Lalor 2001; Pitt et al. 2003, 2008, 2011, 2012; Pitt and Talebi 2013; Pitt and Voorhees 2007, 2011; Sileshi et al. 2014; and Talebi and Pitt 2014).

WinSLAMM continuously models flows and associated hydrographs through stormwater controls. The performance of each stormwater treatment device is dependent on storage volumes, hydraulic controls, and underlying native soils, which can vary greatly. A simple percentage reduction of runoff volume (and concentrations) cannot accurately describe their performance, especially when considering antecedent conditions and variable rainfall characteristics throughout the study period, in addition to complex interconnections of stormwater controls throughout a site. WinSLAMM uses actual long term rainfall history and continuously calculates and routes the flows through stormwater controls. It also considers the undrained volume of water from previous rain events remaining in the control, including moisture levels in treatment media. Runoff volume is infiltrated, and the hydrograph shape is modified based on the stormwater control design. The effluent from an upstream control is then directed to the next downstream control where the runoff volume and hydrograph are similarly altered based on that control design. This process continues until a junction is reached where the multiple flows and hydrographs are combined. This flow and hydrograph routing process continues through the drainage system (which may also incorporate controls, such as grass swales) until the outfall is reached. Outfall controls can also used to alter the runoff volume and hydrograph before the final discharge.

The calculation scheme to predict the performance of biofilters and bioretention controls in WinSLAMM, as described in this paper, has some uncertainties. The predicted results should not be considered extremely precise (as with all stormwater modeling). The data presented in this paper includes measures of uncertainty, expressed as the coefficient of variation (COV), the ratio of the standard deviation to the average value. These can be used in the calculation procedures as part of Monte Carlo calculations where values for a parameter are randomly selected from a probability distribution (as defined by the COV values and distribution type). When this option is selected in WinSLAMM, a random value is selected from the probability distribution for a parameter for each rain event; if the model is run multiple times using the same information and rain series, the final outcomes will vary depending how these random variables interrelate. The final distribution of outcomes usually reasonably represents actual observed variabilities during field monitoring.

With much of the data relying on controlled laboratory and pilot scale experiments, an important question is therefore How well do these results represent actual full scale field measurements as represented in WinSLAMM? A major source of information described in this paper was the laboratory experiments conducted by Pitt and Clark (2010) while developing a media treatment mixture for Boeing for use at the Santa Susana Field Laboratory site in Southern California. The recommended media mixture has been used at many locations on this site. Extensive performance monitoring of the media treatment controls has been conducted over many years. A current set of papers (Pitt et al. 2021a, 2021b) describe how the laboratory test results reasonably agree with the full scale field results, and how performance has changed over many years of operation, as predicted by the laboratory tests and as represented in WinSLAMM.

The steps in sizing a stormwater treatment biofilter, as detailed in the following sections, can be summarized as follows:

1. Characterize the stormwater to be treated (focusing on critical pollutants needing removal together with constituents that affect maintenance), along with the expected runoff volume and flow rates for the drainage area.

2. Determine the required concentrations and mass reductions of the constituents of concern.

3. Identify the chemically active media to target these constituents (including necessary contact times 
and other factors affecting performance, such as anaerobic conditions and degradation of the media along with leaching of constituents from the media).

4. Inventory other site characteristics potentially affecting the biofilter (maximum area available, depth to groundwater and seasonal changes to the water table, underlying natural soil characteristics, snowmelt sodium adsorption ratio, SAR, problems).

5. Prepare preliminary designs addressing these factors (size of facility, selection of media, outlet controls or underdrains, and maintenance intervals).

6. Evaluate alternative designs using long term continuous stormwater quality modeling and evaluate life cycle costs and other decision support factors.

The following section describes some of the data sources and summarizes the statistical tests that were conducted. Illustrative uses of these data are also presented in a later section of this paper.

\section{Data Summaries}

The data and process discussions are separated into three groups: flow rates, particulate retention by particle size, and retention of filterable pollutants. Table 1 lists some characteristics of these materials: percentage of organic matter (affects treatment flow rates), cation exchange capacity (CEC; may affect the retention of cations), \% fines (affects SAR failures with snowmelt), phosphorus content (indicates leaching of phosphorus from media), saturated water content, field capacity, and permanent wilting point (all affect evapotranspiration, ET, losses from media), and the infiltration rates measured for each of these components and mixtures. Table 1 also shows the maximum accumulation of sediment before clogging. An expanded program documentation memo that contains much additional biofilter media information is posted as a white paper on the PV \& Assoc. web page.

Treatment flow rates through biofilter media affect the design and performance of these stormwater controls. High treatment flow rates allow for smaller sized facilities, but also provide reduced contact time between stormwater and media, possibly reducing chemically active treatment in the media. Low treatment flow rates provide longer contact time, and usually better treatment, but require larger treatment areas. Chemically active media also has specific capacities (typically based on ion exchange or sorption processes). Small biofilter facilities with smaller amounts of chemically active media will require more frequent media replacement. In addition, low treatment flow rates and small biofilter surface areas may result in extended standing water above the treatment media, leading to nuisance conditions. The capture of particulate-associated pollutants is not so dependent on the treatment flow rates. However, rapid treatment flow rates with small biofilter surface areas (especially in areas having high sediment loads and lacking pretreatment) can lead to premature failure due to clogging or silting. The media treatment flow rates can be controlled using outlet controls and underdrains, or through mixtures of media components.

Extensive information referenced in Table 1 that was used to calculate the various factors, along with the associated statistical analyses, are included in the appendices and in the white paper available at the WinSLAMM web page.

Table 1 General physical characteristics, treatment flow rates, and retention of stormwater particulates by biofilter media components and mixtures.

(See Appendix)

\subsection{Treatment Flow Rates for Biofilter Media Components and Mixtures}

Biofilter media treatment flow rate measurements were obtained from laboratory and field measurements. The following paragraphs describe the treatment flow rates obtained during two of these research activities. Again, descriptions and data for all of the data are presented in the on-line extended white paper.

Sileshi (2013) conducted a large number of laboratory column tests examining treatment flow rates for various mixtures of stormwater biofilter media as part of his dissertation research. These tests and data are described in his dissertation, available here, and in Sileshi et al. (2014, 2017, 2018). Sileshi (2013) found that the biofilter media treatment flow rates were mostly affected by the median mixture particle size (D50) and the uniformity coefficient (D60/D10) of the media mixture, and the amount of organic matter. As expected, larger particles with small uniformity coefficients had the largest treatment flow rates. Compaction had minor effects if the organic matter content was low, but had significant effects on the flow rates for high organic matter content.

Appendix A1 of Pitt, Clark et al. (2019) lists the characteristics of the media that were tested in the laboratory column tests by Sileshi (2013). The 22 test sand mixtures were prepared to cover the typical range of biofilter media characteristics: the median sizes ranged from $270 \mu \mathrm{m}$ to $1900 \mu \mathrm{m}$ and the uniformity coefficients ranged from 1.3 to 39 . The organic matter content ranged from a low of $1.5 \%$ to a high of about $50 \%$. Tests also included four Tuscaloosa, Alabama area soils and three biofilter media mixtures from existing biofilter facilities. Each test was conducted in triplicate and the resulting saturated flows in the columns were determined together with the media coefficients of variation for three levels of compaction. About 200 column tests were conducted to obtain these data. The test methods, detailed chemical and physical analyses and other supporting information are all described by Sileshi (2013).

Appendix A2 of Pitt, Clark et al. (2019) presents the statistical analyses of these data, building on the factorial test results and analyses presented by Sileshi (2013). The following equations are the resulting significant regression equations developed to calculate the expected saturated flows $(\mathrm{Fc}, \mathrm{cm} / \mathrm{h})$ in $\log 10$ space, based on the D50 ( $\mu \mathrm{m})$ and Cu values. These equations are 
divided by organic matter content (low is $<10 \%$ organic matter and high is $>10 \%$ ) and level of compaction. It is expected that the lowest level of compaction is most commonly used for biofilters, but field monitoring has identified biofilters having high compaction levels. Compaction (listed below as hand compaction, the lowest level of compaction, proctor compaction, and modified proctor compaction, the highest level of compaction normally available) is most important for media mixtures having high organic matter content.

\section{Low Organic Matter Content $(<10 \%$ OM):}

$$
\begin{aligned}
& \text { hand } \log F c=-1.72 \times 10^{-6}\left(D_{50}\right)^{2}+0.00410(C u)^{2}+ \\
& \quad 0.00469\left(D_{50}\right)-0.162(C u) \\
& \text { proctor } \log F c=-1.291 \times 10^{-6}\left(D_{50}\right)^{2}+0.00356(C u)^{2}+ \\
& \quad 0.00407\left(D_{50}\right)-0.175(C u) \\
& \text { modified proctor } \log F c=0.00162\left(D_{50}\right)-0.0590(C u)
\end{aligned}
$$

\section{High Organic Matter Content (>10\% OM):}

$$
\begin{aligned}
& \text { hand } \log F c=1.84+0.000522\left(D_{50}\right)-0.0648(C u) \\
& \text { proctor } \log F c=1.31+0.000683\left(D_{50}\right)-0.0594(C u)
\end{aligned}
$$

$$
\text { modifed proctor } \log F c=1.28+0.000640\left(D_{50}\right)-0.070(C u)(6)
$$

Appendix A2 of Pitt, Clark et al. (2019) contains all of the statistical and regression analyses of variance indicating the significance of the equation terms. The regression behaviors are all reasonable and all coefficients and equations are statistically significant, with the exception of the $\mathrm{Cu}^{2}$ and $\mathrm{Cu}$ terms in the low organic matter low compaction equation which have marginally significant $p$ values at the 0.08 and 0.09 levels, compared to the other coefficients that have significant $p$ values $<0.05$.

In another research example that investigated treatment flow rates, Pitt and Clark (2010) conducted a series of tests while developing treatment media for an industrial site in Southern California. Detailed study descriptions and results are available here.

\subsection{Retention of Stormwater Particulates by Bio- filter Media}

\section{Particulate Retention Equations}

Four main data sources present information for the particulate retention calculations by particle size ranges: column tests (Sileshi 2013); Boeing media tests (Pitt and Clark 2010); Kansas City-USEPA demonstration project biofilters (Pitt et al. 2014); and Wisconsin DNR-USGS biofilter media tests (Bannerman, personal communication). These data are all presented and analyzed in Pitt, Clark et al. (2019).

The following is an example of the test results from one of the test mixtures (the mixture being used by Boeing at many of their stormwater treatment systems) developed by Pitt and Clark
(2010). Extensive laboratory and pilot scale tests were conducted to test and develop this high performance biofilter media mixture to treat a wide range of stormwater pollutants at the Santa Susana Field Laboratory (SSFL), an aerospace and atomic energy test facility located in Southern California, for the Boeing Company, which is being restored. The research report describes the series of different tests conducted with these media. Stormwater particulate retention for different particle sizes was an important parameter in these tests. Table 2 (Pitt and Clark 2010) includes regression equations that were developed and are being used in the WinSLAMM biofilter calculations (an example of one of many media mixtures investigated). Clark and Pitt (2009a) also describe a power equation for particulate retention in the media, while Clark et al. (2006) summarizes some of the earlier test results.

Table 2 Example of removals for rhyolite sand-surface modified zeolite-granular activated carbon mixture (R-SMZ-GAC) for full depth column tests ( $\mathrm{X}$ is the influent concentration and $\mathrm{Y}$ is the calculated effluent concentration).

\section{(See Appendix)}

Full scale test data of biofilter performance (including retention of stormwater particulates) were also used to confirm biofilter media performance derived from controlled column tests. The Kansas City project was a demonstration project funded by the U.S. Environmental Protection Agency (USEPA) to show how green infrastructure can be integrated into areas having combined sewers (Pitt et al. 2014; summarized in Pitt and Talebi 2013). This was an extensive project and included the construction of several hundred stormwater controls in the test area. An adjacent area with no stormwater controls was used for comparison. The monitoring program lasted for $\sim 2 \mathrm{y}$ and included $>50$ storms during the test period. The monitored biofilters worked very well and only 6 events produced underdrain flows that could be sampled and analyzed, with the remainder of the stormwater completely infiltrated after treatment by the media. The media consisted of $30 \%$ planting soil, $20 \%$ organic compost, and $50 \%$ sand (Seattle mix). The performance data for these biofilters are summarized below and the details are shown in the online Appendix C4, with some particulate retention data presented in Table 3 (Pitt et al. 2014).

Full scale biofilter tests were conducted in Neenah, WI by the USGS and Wisconsin DNR (Bannerman, personal communication). These were specially constructed biofilters to compare different mixtures and biofilter designs, specifically targeting phosphorus removal. The data shown below are for mix 2, which consisted of $86 \%$ sand, $11 \%$ peat moss, and $3 \%$ Imbrium phosphorus removal material. The biofilters were sealed under the storage layer and all of the treated effluent was collected by underdrains and analyzed, resulting in 44 sets of data. The performance data for these tests are shown in Table 4 (Bannerman, personal communication), with details provided in the online Appendix C5. 
The summary performance data in these tables indicate the range of influent concentrations for each particle size category, along with the regression equations and the statistical significance of the overall equations and coefficients. In some cases, only the intercepts are significant. In these cases, the effluent is not related to influent concentrations and is a constant value (the COV values can be used with a Monte Carlo procedure to account for the remaining variation). The data from the Wisconsin tests indicated that the data were not normally distributed, so $\log 10$ transformations were used to develop the equations. The Kansas City data did not indicate nonnormal conditions so those data were not transformed. Some of the equations are shown to be highly significant, but there is a lot of variation when the predicted effluent concentrations are compared to the observed effluent concentrations. Therefore, the observed effluent COV values should also be applied to these calculated effluent values using a Monte Carlo process to account for the variability.

Table 3 Kansas City biofilter tests (Seattle biofilter mix; $\mathbf{x}$ is the influent concentration and $y$ is the calculated effluent concentration).

$$
\text { (See Appendix) }
$$

Table 4 Wisconsin media 2 Neenah biofilter tests (mix 2 only available) ( $\mathrm{x}$ is the influent concentration and $\mathrm{y}$ is the calculated effluent concentration).

(See Appendix)

\section{Effects of Solids Accumulation on Flow Rate Reductions}

As solid material accumulates in the biofilter media, the treatment flow rate decreases. Clark (2000) developed clogging equations associated with accumulated loading. Figure 1 shows example plots of the resulting equations for two groups of data: all granular media combined, and a separate plot for compostsand mixtures.

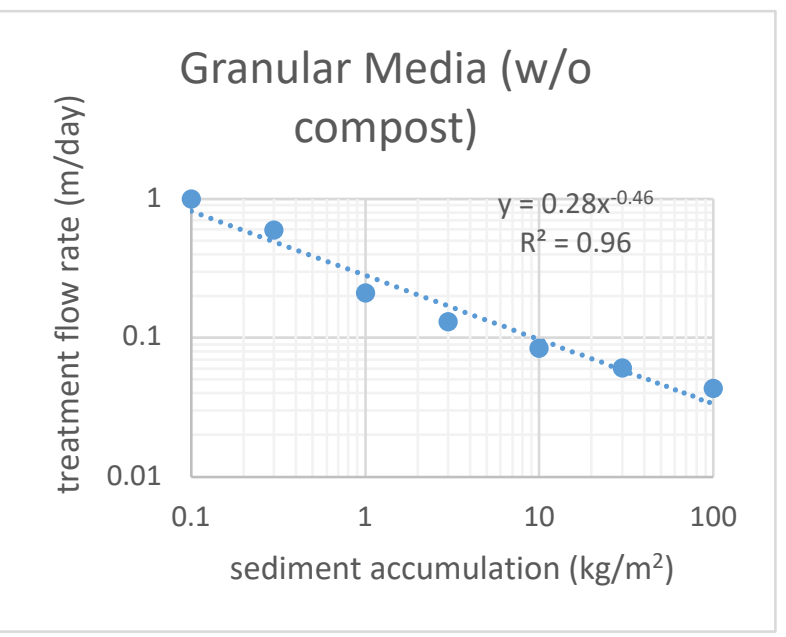

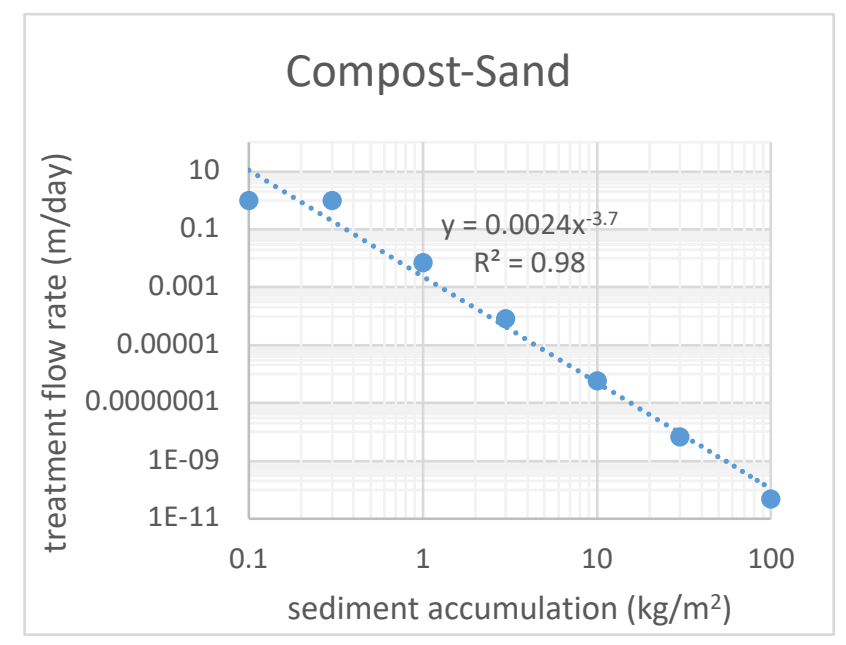

Figure 1 Example of solids accumulation on biofilters and associated treatment flow rate reductions.

These plots show treatment flow rates $(\mathrm{m} / \mathrm{d})$ vs sediment accumulation $\left(\mathrm{kg} / \mathrm{m}^{2}\right)$. The coarse-grained granular media is seen to lose an order of magnitude of flow capacity after about $10 \mathrm{~kg} /$ $\mathrm{m}^{2}$ accumulation. The finer texture and highly variable particle size distribution of the compost-sand resulted in flow rate losses that were much more rapid, with 1 order of magnitude of flow capacity lost after about $0.5 \mathrm{~kg} / \mathrm{m}^{2}$ of sediment accumulation.

\subsection{Retention of Filtered Pollutants by Biofilter Media Components and Mixtures}

The third component of the biofilter calculations is the determination of the retention of filtered pollutants in the media. In most cases, the retention of particulate-bound pollutants will be responsible for most of the total stormwater pollutant reductions in biofilters, but chemically active filter media has also been found to reduce some of the filterable pollutant forms. If the biofilter also has significant infiltration (such as in rain gardens or bioretention facilities with no underdrains, or with high native soil infiltration capacities even with underdrains), it is likely that most of the filtered pollutant mass reductions would be associated with infiltration. The following addresses three aspects of filtered pollutant retention: observed concentration reductions as a function of influent concentrations (with some additional information for bacteria retention and for phosphorus leaching from compost media), media capacity, and the effects of contact time on filtered pollutant retention.

The data associated with these topics for each category are described, with additional background and statistical analysis information given in the on-line appendices. As for the treatment flow calculations, Table 1 includes information for many individual components along with some mixtures. Mass-weighted values for the components are used to calculate these factors for other mixtures, with some restrictions (such as maximum amounts of peat allowed in the mixtures at $50 \%$ to reduce 
compaction issues). Only statistically significant removals are summarized in this paper. If a constituent is not listed for one of the categories, it is assumed that no retention of filtered pollutants occurs (effluent $=$ influent) or that it was not tested.

\subsection{Filterable Pollutant Retention by Media Com- ponents and Mixtures}

\section{Boeing Media Tests}

The Boeing long term column test report (Pitt and Clark 2010) also included detailed analyses of many pollutants in both total and filtered forms. The report statistically analyzed their retention times, which are shown in Table 5 for one example media mixture, with similar data and background statistical tests described in the full report which is available online. Data are shown for conditions generally having $p$ values $\leq 0.05$ (some at 0.06 ). Gross alpha and gross beta removals for the mixtures are shown with $p$ values $\sim 0.13$ due to the small number of tests available. Relationships not shown are for larger $p$ values and in these cases it is assumed that no statistically significant removal occurs (based on the number of samples available) or that it was not tested (listed in the online appendix of of Pitt, Clark et al. (2019), available here) and therefore they were not included in the WinSLAMM calculations.

Table 5 Example of filterable pollutant removals for rhyolite sand-surface modified zeolite-granular activated carbon mixture (R-SMZ-GAC) for full depth column tests ( $x$ is the influent concentration and $y$ is the calculated effluent concentration).

$$
\text { (See Appendix) }
$$

\section{Wisconsin Neenah Media 2 Biofilter Tests}

Additional biofilter data investigating the retention of filtered pollutants is available from the Wisconsin Neenah DNR/USGS tests (Bannerman, personal communication). Table 6 summarizes the observed retention relationships for the media 2 mixture ( $86 \%$ sand, $11 \%$ peat moss and 3\% Imbrium phosphorus removal media). The Wisconsin data are combined from three biofilters, having media depths of $1 \mathrm{ft}-3 \mathrm{ft}(0.3 \mathrm{~m}-0.9 \mathrm{~m})$; no significant differences were noted for the different depths so the data were therefore combined. The influent TDS and chloride values had many nondetectable values, while the effluent values all increased. The increases were due to leaching of salts from the media during long term monitoring.

Table 6 Summary of filtered pollutant retention in Wisconsin media 2 biofilters (Wisconsin Neenah mix: $86 \%$ sand, $11 \%$ peat moss, and $3 \%$ Imbrium) ( $\mathrm{x}$ is the influent concentration and $y$ is the calculated effluent concentration, both in $\log _{10}$ space).

$$
\text { (See Appendix) }
$$

\subsection{Phosphorus Leaching from Compost Amend- ments}

The addition of compost to biofilter mixtures has been shown to add phosphorus to underdrain flows due to leaching of the nutrients from the material. In most cases, relatively small amounts of compost are added (just a few inches of material to the top of the biofilter to support plant growth, or about $10 \%$ of the mixture, for example). The International BMP Database includes effluent concentrations from many typical biofilters indicating about 0.25 $\mathrm{mg} / \mathrm{L}$ filtered phosphorus in the effluent. An extreme example of compost amendments is illustrated in the USEPA report by Pitt et al. (1999), where soil and compost were mixed 50:50 with phosphate subsurface concentrations of about $1.8 \mathrm{mg} / \mathrm{L}$ in the underdrain (compared to about $0.17 \mathrm{mg} / \mathrm{L}$ for soil only test plots).

\subsection{Retention Capacity of Filtered Pollutants in Biofilter Media Components and Mixtures}

There are usually limits on how much of the filtered pollutants can be retained by the biofilter media. Extensive capacity tests were conducted by Pitt and Clark (2010) as part of the Boeing biofilter media development research, as summarized in Tables 7 and 8 (Pitt and Clark 2010). These were determined by long term spiked stormwater column tests to identify when breakthrough occurred. Conventional batch capacity tests are not particularly comparable to field observations, likely because the batch tests use concentrations that are much higher than observed in the field and usually use single component mixtures (Clark and Pitt 2009a, 2009b). These capacities were determined by knowing the amount of pollutants loaded onto the columns during the tests with time until breakthrough, using spiked stormwater mixtures with concentrations similar to those found at the site.

Table 7 Media capacities for filtered pollutants for biofilter media components and mixtures.

\section{(See Appendix)}

Table 8 Media mixture capacities for radioactive stormwater constituents.

(See Appendix)

\subsection{Effects of Contact Time of Filtered Pollutant Retention by Biofilter Media Components and Mixtures}

The Boeing media tests (Pitt and Clark 2010) included measurements to determine the effects on pollutant retention of different contact times of stormwater with the media. These tests were conducted using conventional batch reactor tests and a series of column tests having different media depths. Some losses of retention with increased contact time were noted. This can be caused by leaching of pollutants from the media, additional ion exchange of these constituents with other constituents, or decomposition of the media and release of prior retained 
pollutants. In most cases, the additional contact time results in increased pollutant retention. Some media use (especially peat moss) results in substantial retention of heavy metals with short contact times, while other media may require more than an hour of contact time for the reported retention levels. The following are some of the findings from these media tests for the different media components:

- Granular activated carbon (GAC): most consistent removal and reasonably fast (10 $\mathrm{min}$ ) removal for organic and metallic compounds; however, rapid (6 min) leaching of nutrients and slow leaching ( $>6 \mathrm{~h}$ ) for major ions occurred;

- $\quad$ Surface modified zeolite (SMZ): relatively slow ( $\geq 1 \mathrm{~h}$ ) and less consistent for most constituents: leaching occurred after $\sim 20 \mathrm{~min}$ for nutrients and after $\sim 2 \mathrm{~h}$ for metals;

- $\quad$ Rhyolite sand: relatively fast ( $15 \mathrm{~min})$ for nutrients and slow for major ions and metals (>1.5 h-2.5 h) and no leaching observed;

- $\quad$ Peat: very fast (<5 min) for metals, very slow and inconsistent for other constituents: leaching (or ion exchange additions) of carbon-containing constituents (organic surrogates) occurred after $\sim 10 \mathrm{~min}$ and after $\sim 30$ min for some major ions and nutrients; and

- $\quad$ Site zeolite: very fast (1 $\mathrm{min}$ ) for some organics and nutrients, slow (>1 h-2 h) for major ions and metals; rapid leaching (after $1 \mathrm{~min}$ ) occurred for some major ions and metals.

These contact time tests were only conducted on the individual media components. The combined effects of mixtures in typical biofilters can be calculated based on each constituent. Most biofilters with $0.5 \mathrm{~m}$ of media provide substantial media contact time (up to several hours). WinSLAMM calculates the contact time and modifies the resultant retention associated with leaching.

\section{Numeric Example for Biofilter Media Performance Included in WinSLAMM}

The following is an example that shows how the information from the first part of this paper is used in WinSLAMM to calculate the flow rate through a biofilter, its particulate removal, and filtered pollutant removal performance. Clogging calculations and media sorption capacity are also calculated. This information and process can be used for manual calculations, or alternative models, as desired.

The following describes the hypothetical site and runoff conditions (for one example $25 \mathrm{~mm}$ rain; WinSLAMM is normally used to conduct a continuous simulation of many rains over many years).

\section{Drainage Area}

- 0.4 ha (1 acre) paved commercial parking area.

\section{Stormwater Characteristics}

Particulate-bound pollutants are removed along with the suspended sediment concentration (SSC); only a selection of filtered pollutants is used as examples here (ammonia, nitrates, phosphates, and filtered copper).

- SSC: 300 mg/L (Table 9 shows the particle size distribution, PSD);

- Ammonia as N: $0.9 \mathrm{mg} / \mathrm{L}$;

- Nitrates as N: 20 mg/L;

Phosphates as P: $2.3 \mathrm{mg} / \mathrm{L}$; and

- Cu, filtered: $15 \mu \mathrm{g} / \mathrm{L}$.

Table 9 Example particle size distribution of stormwater particulates.

(See Appendix)

Biofilter Area

- $4 \%$ of paved drainage area $\left(1700 \mathrm{ft}^{2}, 160 \mathrm{~m}^{2}\right)$.

Media Mixture (Well Mixed, Not Layered)

- Granular activated carbon (30\%);

- Peat moss (30\%); and

- Fine sand (40\%).

Media Depth and Void Ratio

- Media depth: $1.5 \mathrm{ft}(0.46 \mathrm{~m})$; and

- Void ratio: $25 \%$.

\subsection{Step 1: Particle Size Distribution of the Media Mixture}

The particle size distribution (PSD) of the media mixture allows the median size $\left(D_{50}\right)$ and the uniformity coefficient $\left(C u=D_{60}\right)$ $D_{10}$ ) to be determined. These values are needed to determine several performance aspects of the biofilter, including the flow rate through the media mixture and the stormwater particulate retention by the media. Table 10 shows the calculations to obtain the mixture PSD. Figure 2 is the PSD plot for the resulting mixture.

Table 10 Calculations to obtain media mixture PSD.

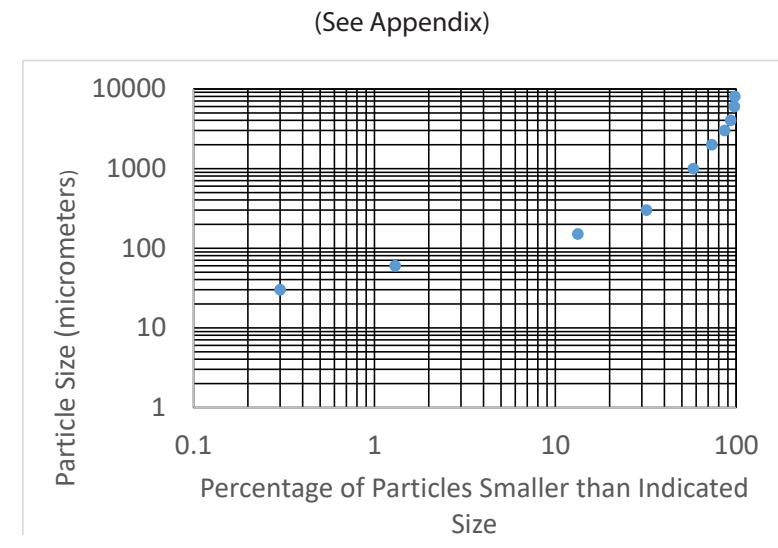

Figure 2 Calculated PSD plot for media mixture. 
The following particle sizes correspond to the associated percentage distributions:

$$
\begin{array}{ll}
\text {. } & \mathrm{D}_{10}: 120 \mu \mathrm{m} ; \\
\text {. } & \mathrm{D}_{50}: 850 \mu \mathrm{m} ; \text { and } \\
\text {. } & \mathrm{D}_{60}: 1100 \mu \mathrm{m} .
\end{array}
$$

The median size for the media mixture is $850 \mu \mathrm{m}$ and the uniformity coefficient $\mathrm{Cu}$ (D60/D10) is 9.2.

\subsection{Step 2: Stormwater Particulate Removal by Particle Size Range}

Stormwater particulate capture for each particle size range is dependent on the influent concentrations and the particle size of the media. The online white paper and appendices (Pitt, Clark et al. 2019) have several tables of removal equations for different conditions, based on Sileshi's (2013) research. Table 11 shows the calculated effluent concentrations using the equations for low to high SSC concentrations (50 mg/L-500 mg/L) and intermediate sized media ( 1000 $\mu \mathrm{m}-2000 \mu \mathrm{m})$.

Table 11 Particulate solids removal calculations.

$$
\text { (See Appendix) }
$$

The particulate solids concentrations decreased from $300 \mathrm{mg} / \mathrm{L}$ to $81 \mathrm{mg} / \mathrm{L}$ for this example event ( $73 \%$ reduction in concentration). The mass concentration reduction could be greater, depending on the runoff volume losses due to infiltration. Particulate forms of other pollutants would also be reduced depending on their association with each particle size range. Currently, WinSLAMM applies the bulk solids reduction (here 73\%) to the particulate pollutant fraction. An upcoming update to WinSLAMM will calculate pollutant reductions based on their specific associations with each size range.

\subsection{Step 3: Stormwater Flow Rate Through Media}

Table 1 listed the treatment flow rates for individual media components and for selected mixtures, which are shown in Table 12 for the three components in this example.

Table 12 Treatment flow rate for media components.

$$
\text { (See Appendix) }
$$

Because of the peat content, special equations using the median particle size and uniformity (and compaction) values are used to calculate the infiltration rate for the media mixture. In this case, the organic content is high ( $>10 \%)$, as the peat fraction is $30 \%$. The equation for hand compaction with high organic matter is:

$$
\log F c=1.84+0.000522\left(D_{50}\right)-0.0648(C u)
$$

For this example, the calculated log $F c$ is 1.68 , and the resulting Fc is therefore $48.7 \mathrm{~cm} / \mathrm{h}$ (19.2 in./h). This is the initial flow rate through the media before it is decreased by clogging.

\subsection{Step 4: Flow Rate Decreases due to Clogging}

Table 1 also includes information concerning the maximum particulate solids loading expected before clogging failure. The clogging value for a mixture is calculated based on the weighted mixture components. Final values much larger than $\sim 20 \mathrm{~kg} /$ $\mathrm{m}^{2}-50 \mathrm{~kg} / \mathrm{m}^{2}$ are suspicious, as that is the value associated with clogging observed in the field. Also, if this value is reached before $\sim 10 \mathrm{y}$, the biofilter will likely cease to function due to clogging. However, if this load value occurs after $10 \mathrm{y}$, and the plants in the biofilter remain healthy and vigorous, the plants can incorporate this material into the surface soil material and the plant roots can keep the system operating (but with reduced surface storage volumes). Table 13 shows this weighted calculation for the maximum sediment load before clogging.

Table 13 Maximum sediment load before clogging for mixture.

\section{(See Appendix)}

The biofilter being examined has a surface area of $\sim 162$ $\mathrm{m}^{2}$. The sediment discharged to the biofilter is calculated for each individual event, and the amount retained is calculated. For a 25 $\mathrm{mm}$ ( $1 \mathrm{in}$.) rain over a 0.4 ha ( 1 acre) paved parking area, the runoff volume would be $\sim 87 \mathrm{~m}^{3}$ (assuming an $R_{v}$ of 0.85 for this drainage area). The SSC concentration is $300 \mathrm{mg} / \mathrm{L}$ and $73 \%$ is retained in the biofilter, based on prior calculations. The total sediment load retained in the biofilter for this event is therefore $\sim 0.12 \mathrm{~kg} /$ $\mathrm{m}^{2}$. The next event would therefore have a slightly reduced flow rate (reduced by the ratio of $0.12 / 21.4)$, or about $48.4 \mathrm{~cm} / \mathrm{h}(19.06$ in./h). After $1 \mathrm{y}$, the total annual accumulation is examined. If it is $>10 \%$ of the maximum (or $2.14 \mathrm{~kg} / \mathrm{m}^{2}$ ), then the rate continues to decrease after each event and the biofilter is shut down due to clogging when the $21.4 \mathrm{~kg} / \mathrm{m}^{2}$ maximum accumulation is reached. For this example, the maximum load may be reached after about $4.6 \mathrm{~m}$ (180 in.) rain. For sites having more than $\sim 0.5$ $\mathrm{m}$ (18 in.) rain/y, the biofilter may prematurely clog. If the total accumulation after one year is $<10 \%$ of the maximum, the biofilter is likely to continue to function without clogging (which requires excellent vegetation cover). In this case, the flow rate is not decreased any further after the first year. However, the surface storage of the biofilter is always decreased after each event based on the accumulated sediment after each rain.

\subsection{Step 5: Retention of Filtered Pollutants}

The online white paper and appendices (Pitt, Clark et al. 2019) contain many equations relating effluent to influent filtered pollutant concentrations for many media types and conditions. Table 5 previously included one media mixture example, from Pitt and Clark (2010). These calculations are only for the filtered forms of the pollutants as the particulate forms are removed along with the particulate solids. Tables 14 and 15 show how these are applied to this example calculation.

Table 14 Filtered pollutant removal equations for example. 
(See Appendix)

Table 15 Filtered pollutant removal calculations.

$$
\text { (See Appendix) }
$$

Step 5.1 Residence and contact time effects on filtered pollutant removal

The contact time of stormwater with the media only affects the filtered pollutants, not the particulate-bound pollutants. Table 16 shows the increased removals (or leaching) after the minimum contact time is reached for the media components in this example. These modifications in removals are only applicable for thin media $(<0.5 \mathrm{~m})$. The prior removal calculations are based on full depth media ( 0.5 m) for well mixed media. Thin layered media results in uneven contact times for each media type, while finer media material mixed with coarse material results in a moderated and constant contact time for all media. The calculated contact time for this media mixture example is $\sim 14 \mathrm{~min}$. Longer contact times can also occur with slowly draining underlying soils beneath biofliters and restricted underdrains. Table 16 shows the contact time effects for the media components for the four filtered pollutants in this example.

Table 16 Effects of contact times on filtered pollutant removals for example.

\section{(See Appendix)}

Ammonia is mostly removed by the rhyolite sand due to the very long contact times required for the GAC and peat for ammonia removal. Nitrate is only shown to be removed by the GAC, while GAC and rhyolite sand affect phosphate, and GAC and peat affect copper for the contact times available.

\section{Step 5.2 Media capacity before breakthrough}

Table 17 lists the media capacities of the different filtered pollutants for various media components for this example.

Table 17 Media pollutant retention capacities of example.

$$
\text { (See Appendix) }
$$

Table 18 shows the weighted capacity of the media mixture for the four filtered pollutants.

Table 18 Total media filtered pollutant retention capacity of example.

$$
\text { (See Appendix) }
$$

\section{Step 5.3 Media run time before breakthrough}

These media capacity values are tracked after each event by WinSLAMM. The filtered pollutant removals do not change as the capacity is consumed, but abruptly cease being retained when the capacities are reached (breakthrough, with effluent concentrations $=$ influent concentrations). Tables 19 and 20 illustrate the media capacity and expected run times before breakthrough for selected pollutants.

Table 19 Total media capacity of example.

$$
\text { (See Appendix) }
$$

Table 20 Expected run times before breakthrough.

$$
\text { (See Appendix) }
$$

The media mixture has limited capacity for phosphate; the ammonia capacity is expected to last slightly longer than for the SSC clogging period; and the capacity for the filtered copper is very large and expected to last for a long period. Negative removals (such as for nitrates) do not imply recovered media capacity but indicate release from the media material.

\section{WinSLAMM Example to Calculate Bio- filter Performance}

The following is an example of analysis of a hypothetical biofilter using WinSLAMM. The calculations are performed within the biofilter component of WinSLAMM to assist in the evaluation of alternative media and biofilter designs. Figure 3 shows a simple flow schematic of a biofilter placed after a 1 acre ( $0.4 \mathrm{ha}$ ) paved parking area in a commercial area. Biofilters can be located at many locations in WinSLAMM, including at many source areas (and in combination with other controls) in many land uses. Figure 4 is the main biofilter input screen where the selection of the components of the biofilter and sizing information is described.

Figure 5 shows part of the media selection menu which calculates the physical properties of the media mixtures, and Figures 6 and 7 are output summaries for this biofilter example.

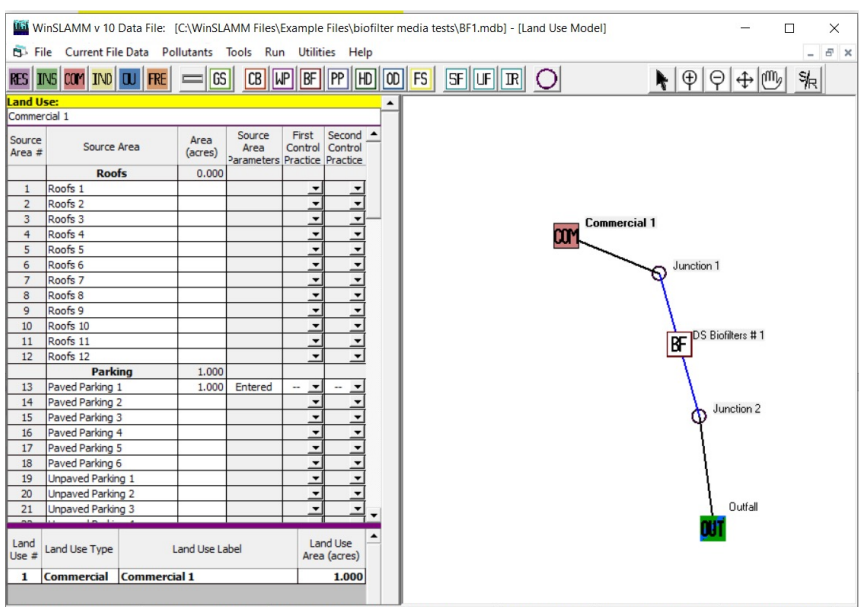

Figure 3 Main WinSLAMM screen showing drainage area and control locations. 


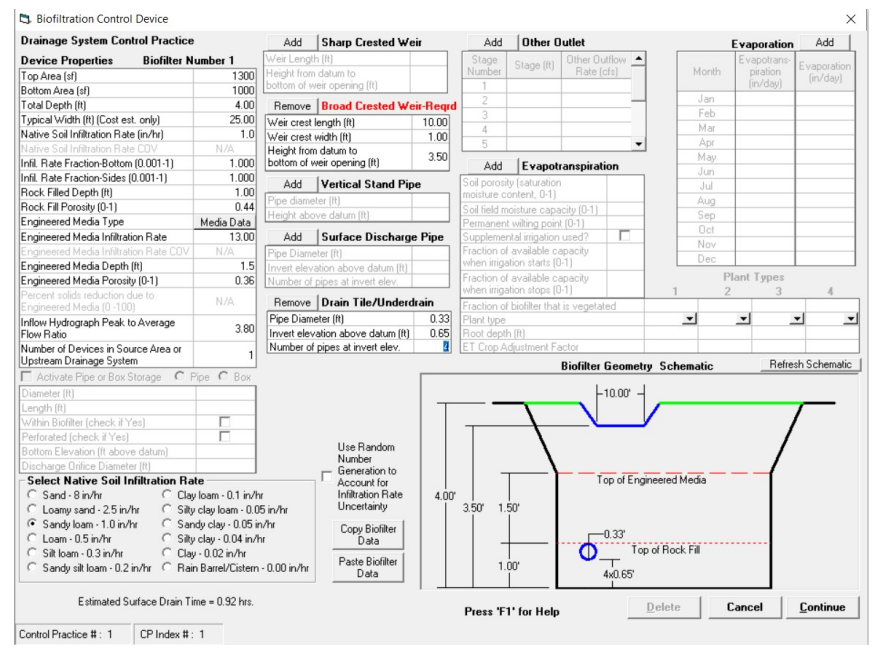

Figure 4 Main WinSLAMM biofilter/bioinfiltration data input form.

\begin{tabular}{|c|c|c|c|c|c|c|}
\hline \multicolumn{7}{|c|}{ Soil, Media Mixtures and Components Table } \\
\hline & $\begin{array}{l}\text { Soil } \\
\text { Type } \\
\text { Texture }\end{array}$ & $\begin{array}{l}\text { Saturation } \\
\text { Water } \\
\text { Content \% } \\
\text { [Porosity] }\end{array}$ & $\begin{array}{l}\text { Field } \\
\text { Capacity } \\
\text { (Percent) }\end{array}$ & $\begin{array}{l}\text { Permanent } \\
\text { Wilting } \\
\text { Point } \\
\text { (Percent] }\end{array}$ & $\begin{array}{l}\text { Infiltration } \\
\text { Rate (in/hr) }\end{array}$ & $\begin{array}{l}\text { Fraction of } \\
\text { Soil Type } \\
\text { Texture in } \\
\text { Engineered } \\
\text { Soil }(0-1)\end{array}$ \\
\hline \multirow{3}{*}{ г } & Sandy Clay & 40 & 34 & 17 & 0.05 & \\
\hline & Silty Clay & 55 & 33.5 & 18 & 0.015 & \\
\hline & Clay & 55 & 33.5 & 18 & 0.015 & \\
\hline \multicolumn{7}{|c|}{ Other Media } \\
\hline & Fine Rhyolite Sand & 38 & 8 & 2.5 & 13 & \\
\hline & Fine Sand & 38 & 8 & 2.5 & 13 & \\
\hline & Filter Sand & 38 & 8 & 2.5 & 13 & 0.700 \\
\hline & Coarse Sand & 32 & 4 & 0 & 40 & \\
\hline & Gravel & 32 & 4 & 0 & 40 & \\
\hline & Light Media for Green Roofs & 50 & 20 & 5 & 13 & \\
\hline \multicolumn{7}{|c|}{ Chemically Active Amendments } \\
\hline & Activated Carbon & 32 & 4 & 0 & 40 & 0.200 \\
\hline & Fine Zeolite & 32 & 4 & 0 & 40 & \\
\hline & Coarse Zeolite & 32 & 4 & 0 & 40 & 0.100 \\
\hline & Compost & 61 & 55 & 5 & 3 & \\
\hline & Peat Moss & 78 & 59 & 5 & 5.8 & \\
\hline \multicolumn{7}{|c|}{ User Defined Amendments } \\
\hline \multicolumn{7}{|c|}{ Phosphorus Sorption Media } \\
\hline \multicolumn{7}{|c|}{$\begin{array}{l}\text { Biochar } \\
\text { Pre-Defined Media Mixtures }\end{array}$} \\
\hline \multicolumn{7}{|c|}{ Pre-Defined Media Mixtures } \\
\hline & Rhyolite Sand - SMZ & 43 & 4 & 0 & 25 & \\
\hline & Rhyolite Sand - SMZ-GAC & 41 & 4 & 0 & 25 & \\
\hline & Rhyolite Sand - SMZ-GAC.PM & 43 & 10 & 0.5 & 25 & \\
\hline & Iron Fillings $(7.5 \%) /$ Sand & 38 & 8 & 2.5 & 13 & \\
\hline & Iron Fillings $(10.2 \%) /$ Sand & 38 & 8 & 2.5 & 13 & \\
\hline \multicolumn{7}{|c|}{ Biofilter Media Mixtures } \\
\hline & Kansas City & 40 & 12 & 10 & .55 & \\
\hline & Wisconsin 1 & 40 & 10 & 5 & 25.1 & \\
\hline & Wisconsin 2 & 40 & 10 & 5 & 20.5 & \\
\hline & North Carolina & 40 & 7 & 5 & 18.7 & \\
\hline \multicolumn{2}{|r|}{ Composite Soil Mixture Properties } & 36.2 & 6.8 & 1.8 & 13.000 & 1.000 \\
\hline \multirow{2}{*}{\multicolumn{2}{|c|}{$\begin{array}{c}\text { Apply Soil Mixture Values } \\
\text { as a User Defined Soil } \\
\text { Mixture }\end{array}$}} & $\sqrt{\nabla} \stackrel{\text { Apply }}{\text { Porosity }}$ & $\begin{array}{l}\text { 『pply } \\
\nabla \text { Field } \\
\text { Capacity }\end{array}$ & $\begin{array}{l}\text { Apply } \\
\text { 『 Wilting } \\
\text { Point }\end{array}$ & $\begin{array}{l}\text { Apply } \\
\text { 『 Infiltration } \\
\text { Rate }\end{array}$ & $\nabla \begin{array}{l}\text { Apply } \\
\text { All } \\
\text { Values }\end{array}$ \\
\hline & & & & Cancel & Contint & nue \\
\hline
\end{tabular}

Figure 5 Media component input form.

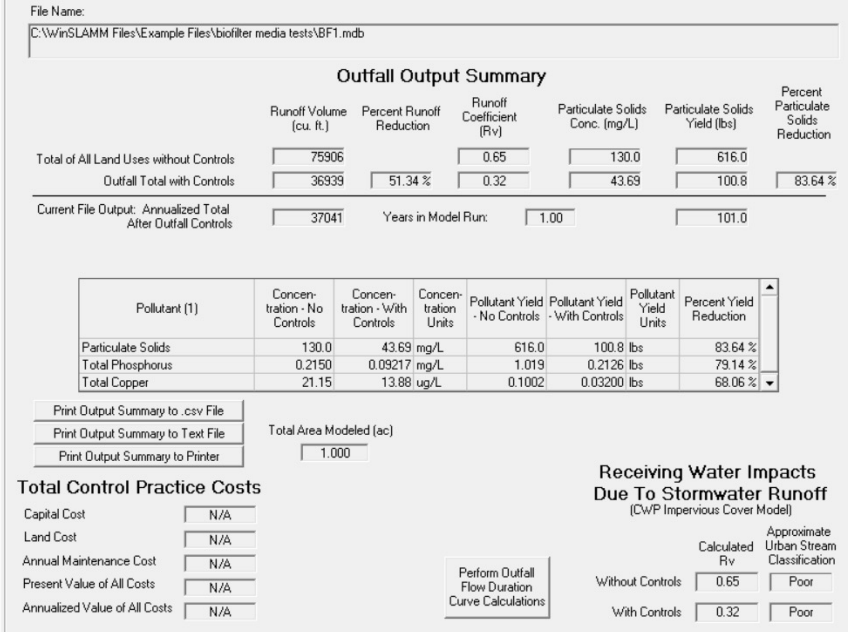

Figure 6 WinSLAMM output summary.

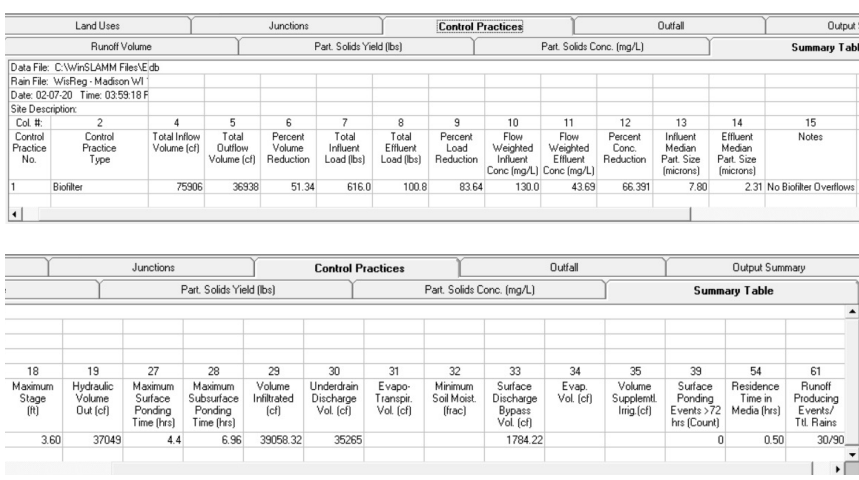

Figure 7 Control practice output screen.

This example was rerun several times with varying paved drainage areas, while keeping the biofilter design constant. Figure 8 is the resulting production function comparing the annual runoff volume and particulate reduction for different footprint areas of the biofilter.

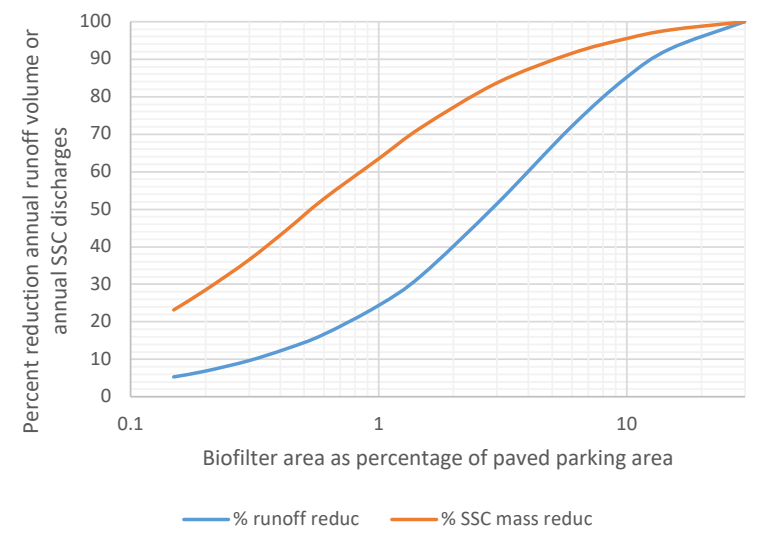

Figure 8 Production function comparing biofilter performance for different biofilter sizes. 
As the biofilter area increases (as a percentage of the paved parking area), the percentage reductions in the runoff volume and the particulate loads increase. As an example, if there was a requirement for $80 \%$ particulate reductions, the biofilter in this example would need to be about $2 \%$ of the paved drainage area. A biofilter of this relative size would also provide about $40 \%$ runoff volume reductions. Obviously, this production function relationship varies for different media, hydraulic outlets and controls, rain amounts, and maintenance intervals.

The analyses also provided data to calculate the particulate mass loading on the biofilter, as shown on Figure 9. The unit area clogging associated load is about $25 \mathrm{~kg} / \mathrm{m}^{2}$ of biofilter area. If this occurs over $\sim 10$ y or longer $\left(<2.5 \mathrm{~kg} / \mathrm{m}^{2} / \mathrm{y}\right)$ for a well vegetated and well maintained biofilter, the biofilter is likely to retain satisfactory treatment flow rates without clogging failure (but with potential chemical breakthrough failure). This particulate solids accumulation rate would require a biofilter of at least $2.5 \%$ of the paved drainage area. Smaller biofilters would likely clog prematurely as the plants may not be able to incorporate the deposited material into the surface soils and root zone of the system. If the biofilter was only about $1 \%$ of the paved parking area, this critical load could occur within $2 y-3 y$, requiring relatively frequent media replacement.

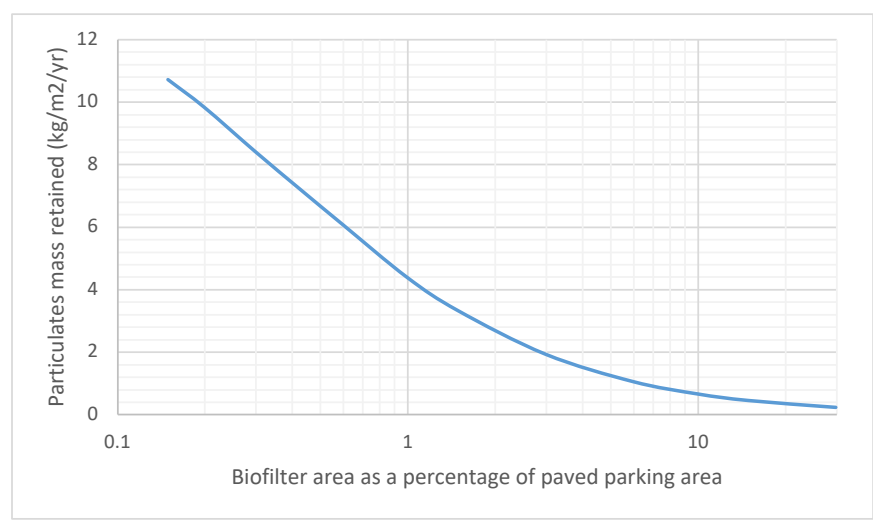

Figure 9 Plot of cumulative load and useful life of media in biofilter.

\section{Conclusions}

Performance data from a number of laboratory and field studies of biofilter media were used to examine the important unit operation components that could be used to calculate the water quality and quantity benefits of different media mixtures in WinSLAMM. Treatment flow rates are mostly affected by the texture of the media (median size and uniformity coefficient) and organic content. Compaction of the media also can significantly decrease the treatment flow rates. Mixtures of media, such as the use of fine sands with coarse media, or with compost or peat, moderate the flow rates and contact times while protecting the organic media from excessive compaction.
The retention of stormwater particulates in biofilters (and subsequent clogging) is also dependent on the media texture. It is important that the retention and clogging calculations be applied to different stormwater particle size classes. Large particulates greater than about $100 \mu \mathrm{m}$ are very effectively retained, while small particles are less effectively retained by most media mixtures. Fine silt and clay particles also move further through the media while the coarse material is mostly retained on the media surface. This behavior also affects the clogging of the media and only a temporary benefit is associated with replacing the top layers of the media, rather than total media replacement, when excessive surface ponding occurs.

Pollutants associated with the particulates in the stormwater are retained along with the particulates. The particulate strengths (mg pollutant/kg SSC) vary for different stormwater particle sizes and pollutants, so these factors are also used in the performance calculations. Filtered forms of the stormwater pollutants are retained in the media usually through combinations of ion exchange and sorption on to the media. This retention is dependent on the ability of the media to capture the specific pollutants for the available contact times of the stormwater with the media. Thus media having high treatment flow rates can result in smaller biofilter footprints to capture stormwater from a drainage area compared to media having lower flow rates. Particulate retention is not greatly affected by flow rate, so media selection may be determined by the service life of the media before clogging requires media replacement and the need to retain specific pollutants for desirable contact times.

This paper only contains summaries of some of the available data used in WinSLAMM. The web-posted white paper modeling documentation, (Pitt, Clark et al. 2019; available here) shows the full datasets used, along with the statistical analyses and final equation forms used in the model. As with any model, uncertainty is associated with both the processes and the data. The data presented in this paper represent a wide range of conditions and locations, but it is possible that greater uncertainty may occur for specific uses and locations. The white paper includes considerations of confidence associated with the analyses, and the presented data and processes rely only on statistically significant relationships and findings. In all cases, all models require calibration and verification for local use.

This paper also shows how these data are used to calculate the performance of biofilters and contains an example of biofilter performance calculations using WinSLAMM. These processes and data can be used in manual calculations or other models. The calculation processes consist of the following components:

- Particle size distribution of the media mixture;

- Stormwater particulate removal by particle size range;

- Stormwater flow rate through media;

- Flow rate decreases due to clogging; and

- Retention of filtered pollutants (including effects of contact time and capacity before breakthrough). 
Media selection dramatically affects the treatment flow rate and the pollutant retention capacity of a biofilter. Most of the pollutant removals in bioinfiltration are likely through infiltration into the underlying native soils (with pretreatment provided by the media), while physical capture of particulates and associated particulate bound pollutants is mostly affected by the texture and uniformity of the media. Filtered pollutant retention in biofilters can be targeted by the selection of chemically active media. Biofilter performance can be limited by poor media selection causing compaction and clogging. The most robust biofilters are sized properly to decrease the effects of sediment induced clogging and to provide moderate treatment flow rates. The use of WinSLAMM can be used to produce production functions that relate cumulative load with size of the biofilter and useful life for specific site conditions and expected rainfall.

\section{Acknowledgments}

We thank the many sponsors who supported the biofilter research noted in this paper, especially the Boeing Company for developing treatment media for the Santa Susana Field Laboratory, and the USEPA's Storm and Combined Sewer Section in Edison, NJ. These research projects were conducted at the University of Alabama at Birmingham, the University of Alabama, and Penn State-Harrisburg, with the dedicated assistance of many undergraduate and graduate students. This support over the past 30 plus years is gratefully acknowledged.

\section{References}

Avila, H., and R. Pitt. 2009. “Scour in Stormwater Catchbasin Devices-Experimental Results from a Full-Scale Physical Model." Journal of Water Management Modeling 17: R235-19. https://doi.org/10.14/JWMM.R235-19.

Avila, H., R. Pitt, and S.R. Durrans. 2008. "Factors Affecting Scour of Previously Captured Sediment from Stormwater Catchbasin Sumps." Journal of Water Management Modeling 16: R228-13. https://doi.org/10.14796/JWMM.R228-13.

Clark, S. 1996. Evaluation of filtration media for stormwater runoff treatment. Birmingham, AL: University of Alabama at Birmingham. MScE thesis.

Clark, S. 2000. Urban stormwater filtration: optimization of design parameters and a pilot-scale evaluation. Birmingham, AL: University of Alabama at Birmingham. Ph.D. Dissertation.

Clark, S., and R. Pitt. 1999. Evaluation of filtration media for stormwater treatment. Stormwater Treatment at Critical Areas, Vol. 3. Cincinnati, OH: U.S. Environmental Protection Agency, Water Supply and Water Resources Division, National Risk Management Research Laboratory. EPA/600/R-00/016.
Clark, S., and R. Pitt. 2009b "Stormwater filter media pollutant retention under aerobic versus anaerobic conditions." Journal of Environmental Engineering 135 (5): 367-71.

Clark, S, and R. Pitt. 2009a "Solids removal in stormwater filters modeled using a power equation." Journal of Environmental Engineering 135 (9): 896-9.

Clark. S., and R. Pitt. 2012. "Targeting treatment technologies to address specific stormwater pollutants and numeric dis-charge limits." Water Research 46: 6715-30.

http://www.sciencedirect.com/science/article/pii/ S0043135412004915

Clark, S., R. Pitt, P.D. Johnson, S. Gill, and M. Pratap. 2006. "Media filtration to remove solids and associated pollutants from stormwater runoff." In Best Management Practices (BMP) Technology Symposium: Current and Future Directions, ch. 7, 141-163. Reston, VA: American Society of Civil Engineers.

Myllyoja, R., H. Baroudi, R. Pitt, and J. Paluzzi. 2001. "Use of SLAMM in Evaluating Best Management Practices." Journal of Water Management Modeling 09: R207-08. https://doi.org/10.14796/JWMM.R207-08.

Pitt, R. 1997. “Unique Features of the Source Loading and Management Model (SLAMM)." Journal of Water Management Modeling 06: R200-02. https://doi.org/10.14796/JWMM.R200-02.

Pitt, R. 1999. "Small Storm Hydrology and Why it is Important for the Design of Stormwater Control Practices." Journal of Water Management Modeling 07: R204-04. https://doi.org/10.14796/JWMM.R204-04.

Pitt, R.E., S. Chen, S. Clark, J. Lantrip, C.K. Ong, and J. Voorhees. 2003. "Infiltration Through Compacted Urban Soils and Effects on Biofiltration Design."Journal of Water Management Modeling 11: R215-12. https://doi.org/10.14796/JWMM.R215-12.

Pitt, R., and S. Clark. 2010. Evaluation of biofiltration media for engineered natural treatment systems. Seattle, WA: Geosyntec Consultants and The Boeing Co. http://www.boeing.com/principles/environment/santa-susana/technical-reports.page (under Expert Panel/Expert Panel Evaluation of Biofiltration Media for Engineered Natural Treatment Systems May 10, 2010).

Pitt, R., S. Clark, R. Sileshi, and J. Voorhees. 2019. "Biofilter media performance updates for WinSLAMM." http://winslamm.com/docs/biofilter\%20media\%20performance\%20updates\%20Dec\%2026\%202019.pdf

Pitt, R., and M. Lalor. 2001. “The Role of Pollution Prevention in Stormwater Management." Journal of Water Management Modeling 09: R207-01. https://doi.org/10.14796/JWMM.R207-01. 
Pitt, R., and J. Lantrip. 2000. "Infiltration Through Disturbed Urban Soils." Journal of Water Management Modeling 08: R206-01 https://doi.org/10.14796/JWMM.R206-01.

Pitt, R., J. Lantrip, R. Harrison, C. Henry, and D. Hue. 1999. Infiltration through disturbed urban soils and compost-amended soil effects on runoff quality and quantity. Cincinnati, OH: U.S. Environmental Protection Agency, Water Supply and Water Resources Division, National Risk Management Research Laboratory. EPA 600/R-00/016.

Pitt, R., M. Otto, A. Questad, S. Isaac, M. Coyer, B. Steets, R. Gearheart, J. Jones, M. Josselyn, M. Stenstrom, S. Clark, P. Costa, and J. Wokurka. 2021a. "Laboratory media test comparisons to long-term performance of biofilter, media filter, and treatment-train stormwater controls." Journal of Sustainable Water in the Built Environment.

Pitt, R., M. Otto, A. Questad, S. Isaac, M. Coyer, B. Steets, R. Gearheart, J. Jones, M. Josselyn, M. Stenstrom, P. Costa, and J. Wokurka. 2021b. “Changes in performance during longterm monitoring of full-scale media filter stormwater controls at an industrial site." Submitted to Journal of Sustainable Water in the Built Environment.

Pitt, R., and L. Talebi. 2012. Evaluation and demonstration of stormwater dry wells and cisterns in Milburn Township, New Jersey. Edison, NJ: U.S. Environmental Protection Agency, Urban Watershed Management Branch.

Pitt, R., L. Talebi, D. O'Bannon, D. Bambic, and J. Wright. 2014. "Modeling of green infrastructure components and largescale test and control watersheds at Kansas City, MO," Prepared for USEPA and Tetra Tech. http://unix.eng.ua.edu/ rpitt/Publications/5_Stormwater_Treatment/GI_controls/Green_Infrastructure_and_ WinSLAMM_Modeling_at_KC.pdf

Pitt, R., and J. Voorhees. 2002. "SLAMM, the Source Loading and Management Model." Wet-Weather Flow in the Urban Watershed (Edited by Richard Field and Daniel Sullivan). CRC Press, Boca Raton. pp 103-139.

Pitt, R.E., and J. Voorhees. 2007. “Using Decision Analyses to Select an Urban Runoff Control Program." Journal of Water Management Modeling 15: R227-04. https://doi.org/10.14796/JWMM.R227-04.

Pitt, R., and J. Voorhees. 2011. “Modeling Green Infrastructure Components in a Combined Sewer Area." Journal of Water Management Modeling 19: R241-08. https://doi.org/10.14796/JWMM.R241-08.

Pitt, R.E., J. Voorhees, and C. Burgess. 2012. "Simple Hydrograph Shapes for Urban Stormwater Water Quality Continuous Analyses." Journal of Water Management Modeling 20: R245-16. https://doi.org/10.14796/JWMM.R245-16.
Pitt, R.E., S. Clark, P. Johnson and J. Voorhees. 2008. "Evapotranspiration and Related Calculations for Bioretention Devices." Journal of Water Management Modeling 16: R228-19. https://doi.org/10.14796/ JWMM.R228-19.

Pitt, R.E., J. Voorhees, and S. Clark. 2011. “Continuous Long-term Simulations for Evaluating Storage Treatment Design Options of Stormwater Filters." Journal of Water Management Modeling 19: R241-07. https://doi.org/10.14796/JWMM.R241-07.

Sileshi, R. 2013. Soil physical characteristics related to failure of stormwater bioinfiltration devices. PhD dissertation. Birmingham, AL: The University of Alabama, Department of Civil, Constructions, and Environmental Engineering. PhD dissertation.

http://unix.eng.ua.edu/ rpitt/Publications/11_Theses_ and_Dissertations/Redi_dissertation.pdf

Sileshi, R., R.E. Pitt, and S. Clark. 2014. “Laboratory Column Test for Predicting Changes in Flow with Changes in Various Biofilter Mixtures." Journal of Water Management Modeling 22: C373. https://doi.org/10.14796/JWMM.C373.

Sileshi, R., R. Pitt, and S. Clark. 2017. "Impacts of soil media characteristics on stormwater biofiltration system performance." International Advanced Research Journal in Science, Engineering and Technology (IARJSET) 4 (3). http://www.iarjset.com/upload/2017/march-17/IARJSET\%2022.pdf

Sileshi, R., R. Pitt, and S. Clark. 2018. "Performance evaluation of an alternative underdrain material for stormwater biofiltration systems." ASCE Journal of Sustainable Water in the Built Environment.

Talebi, L., and R.E. Pitt. 2014. “Evaluation and Demonstration of Stormwater Dry Wells and Cisterns in Millburn Township, New Jersey." Journal of Water Management Modeling 22: $\mathrm{C} 376$. https://doi.org/10.14796/JWMM.C376.

Talebi, L. 2014. Assessment of Integrated Green InfrastructureBased Stormwater Controls in Small to Large Scale Developed Urban Watersheds. Ph.D. Dissertation, Dept. of Civil, Construction, and Environmental Engineering, University of Alabama.

http://unix.eng.ua.edu/ rpitt/

Publications/11_Theses_and_Dissertations/ Leila_Dissertation.pdf

An expanded white paper with appendices describing the data sources and references, along with the statistical analyses used in this paper, is available at the PV \& Assoc. web site. 


\section{Appendix: Tables}

Table 1 General physical characteristics, treatment flow rates, and retention of stormwater particulates by biofilter media components and mixtures.

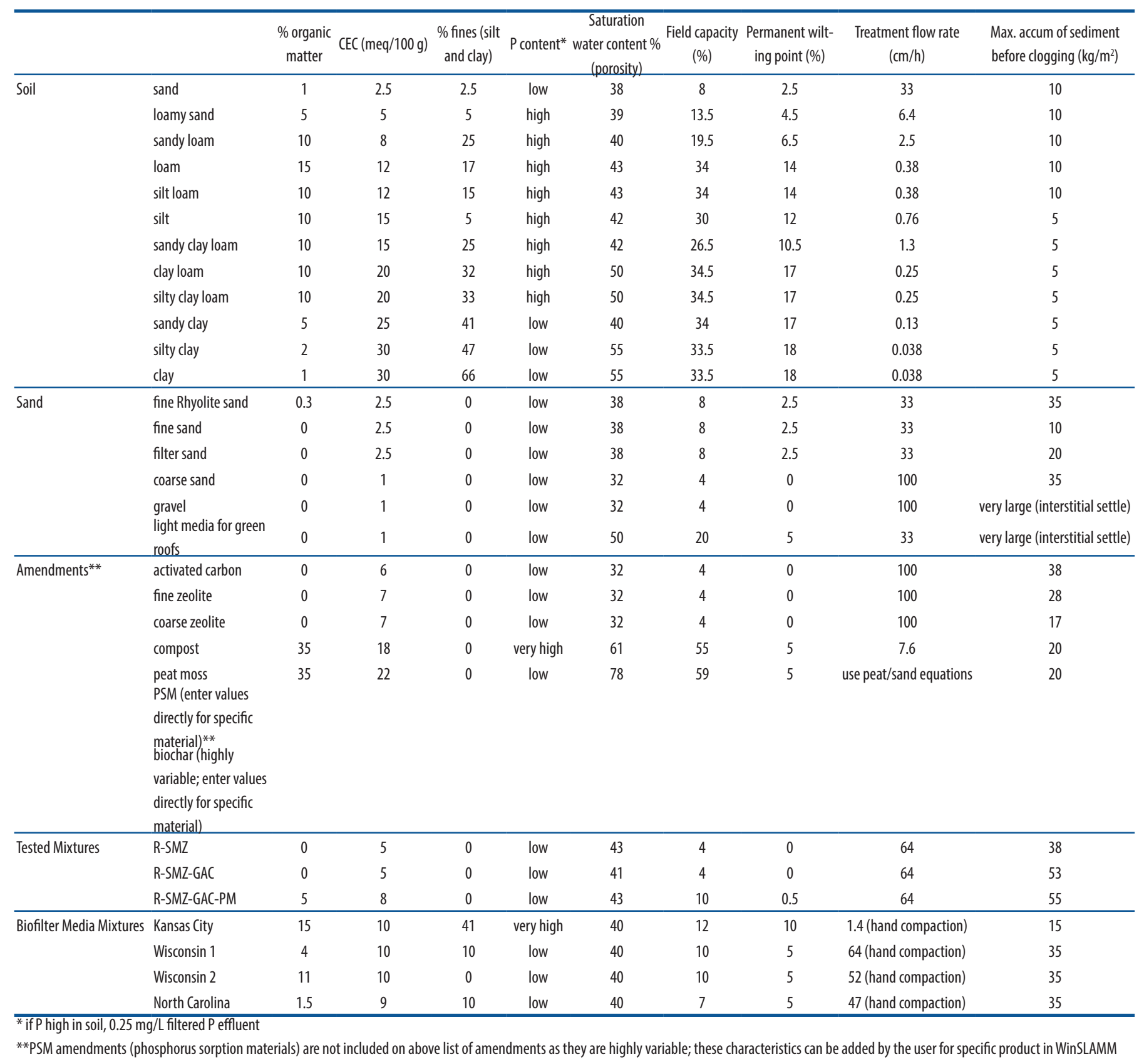


Table 2 Example of removals for rhyolite sand-surface modified zeolite-granular activated carbon mixture (R-SMZ-GAC) for full depth column tests ( $\mathrm{X}$ is the influent concentration and $\mathrm{Y}$ is the calculated effluent concentration).

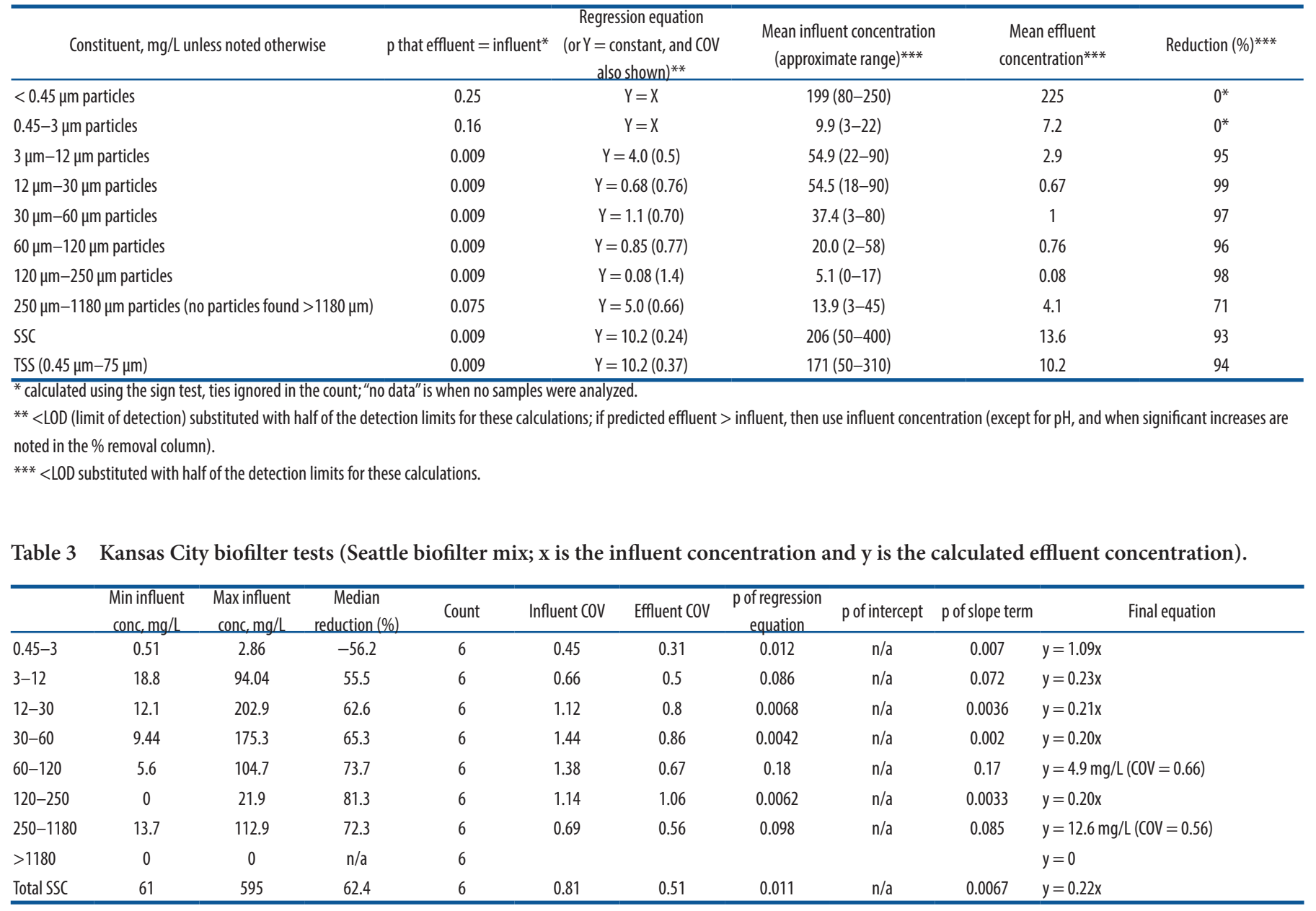

Table 4 Wisconsin media 2 Neenah biofilter tests ( $\mathrm{mix} 2$ only available) ( $\mathrm{x}$ is the influent concentration and $\mathrm{y}$ is the calculated effluent concentration).

\begin{tabular}{|c|c|c|c|c|c|c|c|c|c|c|}
\hline & $\begin{array}{l}\text { Min influent } \\
\text { conc, mg/L }\end{array}$ & $\begin{array}{l}\text { Max influent } \\
\text { conc, mg/L }\end{array}$ & $\begin{array}{c}\text { Median } \\
\text { reduction (\%) }\end{array}$ & Count & Influent COV & Effluent COV & $\begin{array}{c}\text { p of regression } \\
\text { equation }\end{array}$ & p of intercept & p of slope term & Final equation \\
\hline $0.45-2$ & 0.56 & 60 & 56 & 44 & 1.3 & 0.72 & $2.10 \times 10^{-5}$ & $\mathrm{n} / \mathrm{a}$ & $2.00 \times 10^{-5}$ & $\log$ effluent $=0.35$ (log influent) \\
\hline $2-4$ & 0.07 & 86 & 86 & 44 & 2.4 & 0.81 & 0.017 & $2.20 \times 10^{-11}$ & 0.017 & $\log$ effluent $=-0.74+0.32$ (log influent) \\
\hline $4-8$ & 0.03 & 36 & 89 & 44 & 1.8 & 0.88 & 0.0086 & $1.30 \times 10^{-17}$ & 0.0086 & $\log$ effluent $=-1.04+0.32$ (log influent) \\
\hline $8-16$ & 0.04 & 29 & 90 & 44 & 1.5 & 0.91 & 0.011 & $5.40 \times 10^{-15}$ & 0.011 & $\log$ effluent $=-0.99+0.33$ (log influent) \\
\hline $16-31$ & 0.08 & 23 & 93 & 44 & 1.3 & 0.85 & 0.046 & $1.70 \times 10^{-12}$ & 0.046 & $\log$ effluent $=-0.97+0.33$ (log influent) \\
\hline $31-63$ & 0.96 & 52 & 88 & 44 & 1.2 & 1.2 & 0.00014 & $\mathrm{n} / \mathrm{a}$ & 0.00014 & effluent $=0.48 \mathrm{mg} / \mathrm{L} ; \mathrm{COV}=1.2$ \\
\hline $63-125$ & 0.8 & 52 & 90 & 44 & 1 & 0.92 & 0.0027 & $\mathrm{n} / \mathrm{a}$ & 0.0027 & effluent $=0.65 \mathrm{mg} / \mathrm{L} ; \mathrm{COV}=0.92$ \\
\hline $125-250$ & 0.27 & 41 & 88 & 44 & 0.95 & 1.2 & 0.6 & 0.00081 & 0.6 & effluent $=0.40 \mathrm{mg} / \mathrm{L} ; \mathrm{COV}=1.2$ \\
\hline $250-500$ & 0.02 & 33 & 87 & 40 & 1.8 & 1.4 & 0.31 & $2.30 \times 10^{-7}$ & 0.31 & effluent $=0.34 \mathrm{mg} / \mathrm{L} ; \mathrm{COV}=1.4$ \\
\hline$>500$ & 0.14 & 54 & 86 & 43 & 1.8 & 1.2 & 0.76 & 0.00027 & 0.76 & effluent $=0.32 \mathrm{mg} / \mathrm{L} ; \mathrm{COV}=1.2$ \\
\hline SSC & 4 & 262 & 82 & 44 & 1 & 0.65 & 0.13 & 0.0011 & 0.13 & effluent $=6 \mathrm{mg} / \mathrm{L} ; \mathrm{COV}=0.65$ \\
\hline
\end{tabular}


Table 5 Example of filterable pollutant removals for rhyolite sand-surface modified zeolite-granular activated carbon mixture (R-SMZ-GAC) for full depth column tests ( $\mathrm{x}$ is the influent concentration and $\mathrm{y}$ is the calculated effluent concentration).

\begin{tabular}{|c|c|c|c|}
\hline $\begin{array}{c}\text { Constituent, } \mathrm{mg} / \mathrm{L} \text { unless } \\
\text { noted otherwise }\end{array}$ & $\begin{array}{l}p \text { that effluent } \\
=\text { influent }^{*}\end{array}$ & $\begin{array}{l}\text { Regression equation } \\
\text { (or } \mathrm{Y}=\text { constant, and } \\
\text { (OV also shown)** }\end{array}$ & $\begin{array}{l}\text { Mean influent concentra- } \\
\text { tion (approximate range) }\end{array}$ \\
\hline Chloride & 0.063 & $Y=30(0.18)$ & $18(1-34)$ \\
\hline Fluoride & 0.063 & $Y=2.2(0.25)$ & $2.6(1.7-3.1)$ \\
\hline Sulfate, as $\mathrm{SO}_{4}$ & 0.063 & $Y=37(0.29)$ & $45(39-51)$ \\
\hline Boron & 0.031 & almost all effluent $<\mathrm{LOD}$ & $170(<L 0 D-509)$ \\
\hline Ammonia, as N & 0.008 & $Y=0.013(1.4)$ & $2.7(0.3-3.9)$ \\
\hline Nitrite + nitrate as $\mathrm{N}$ & 0.063 & $Y=3.0(0.84)$ & $6.0(4.9-7.1)$ \\
\hline Gross alpha radioactivity, $\mathrm{pCi} / \mathrm{L}$ & 0.125 & all effluent $<$ LOD & $5.3(3.9-6.8)$ \\
\hline Uranium, pCi/L & 0.125 & all effluent $\angle L O D$ & $1.2(1.1-1.5)$ \\
\hline Radium $226+228, \mathrm{pCi} / \mathrm{L}$ & 0.125 & $Y=0.31(1.2)$ & $0.92(0.67-1.2)$ \\
\hline Arsenic, filtered & 0.109 & $Y=14(0.34)$ & $33(<L O D-109)$ \\
\hline Aluminum, filtered & 0.008 & $Y=45(0.39)$ & $73(<\mathrm{LOD}-121)$ \\
\hline Boron, filtered & 0.031 & all effluent $<$ LOD & $177(<\mathrm{LOD}-472)$ \\
\hline Cadmium, filtered & 0.008 & almost all effluent $<L O D$ & $28(1-54)$ \\
\hline Copper, filtered & 0.004 & $Y=13(0.40)$ & $42(23-69)$ \\
\hline Iron, filtered & 0.008 & $Y=0.37 X$ & $63(44-109)$ \\
\hline Magnesium, filtered & 0.004 & $Y=4300(0.39)$ & $2480(2140-3520)$ \\
\hline Manganese, filtered & 0.125 & almost all effluent $<\mathrm{LOD}$ & $3.4(<\mathrm{LOD}-13)$ \\
\hline Nickel, filtered & 0.004 & $Y=0.3 X$ & $27(7-68)$ \\
\hline Potassium, filtered & 0.004 & $Y=8000(0.23)$ & $2410(1960-3250)$ \\
\hline Chromium, filtered & 0.004 & $Y=0.27 X$ & $14(7-19)$ \\
\hline Thallium, filtered & 0.004 & almost all effluent $<\mathrm{LOD}$ & $64(27-94)$ \\
\hline Antimony, filtered & 0.035 & $Y=34(0.39)$ & $56(39-86)$ \\
\hline Nitrate, mg/L & 0.063 & $Y=3.0(0.88)$ & $6.0(4.9-7.1)$ \\
\hline \multicolumn{4}{|c|}{$\begin{array}{l}\text { *values }<0.05 \text { are statistically significant, while slightly larger values shown indicate marginal } \\
\text { significance } \\
\text { **if the slope term is not significant, the effluent concentration is assumed to be not related to the } \\
\text { influent concentration and the average effluent value is shown, along with the COV to indicate the } \\
\text { variability }\end{array}$} \\
\hline
\end{tabular}

Table 6 Summary of filtered pollutant retention in Wisconsin media 2 biofilters (Wisconsin Neenah mix: $86 \%$ sand, $11 \%$ peat moss, and $3 \%$ Imbrium) ( $x$ is the influent concentration and $y$ is the calculated effluent concentration, both in $\log _{10}$ space).

\begin{tabular}{|c|c|c|c|c|c|c|c|c|c|c|c|}
\hline & $\begin{array}{c}\% \text { of influent } \\
\text { values ND }\end{array}$ & $\begin{array}{c}\% \text { of effluent } \\
\text { values ND }\end{array}$ & $\begin{array}{l}\text { in influer } \\
\text { conc }\end{array}$ & $\begin{array}{l}\text { Max influent } \\
\text { conc }\end{array}$ & $\begin{array}{c}\text { Median } \\
\text { reduction (\%) }\end{array}$ & $\begin{array}{c}\text { Count (includ- } \\
\text { ing ND) }\end{array}$ & Influent COV & $\begin{array}{c}\text { p of regression } \\
\text { equation }\end{array}$ & $\begin{array}{c}\mathrm{p} \text { of } \\
\text { intercept }\end{array}$ & $\begin{array}{c}\text { p of slope } \\
\text { term }\end{array}$ & Final equation \\
\hline $\mathrm{TDS}(\mathrm{mg} / \mathrm{L})$ & $69 \%$ & $0 \%$ & $<50$ & 152 & -320 & 48 & 0.8 & $5.00 \times 10^{-16}$ & $\mathrm{n} / \mathrm{a}$ & $6.00 \times 10^{-17}$ & ${ }^{7} \log$ effluent $=1.187(\log$ influent $)$ \\
\hline Filtered phosphorus (mg/L) & $0 \%$ & $0 \%$ & 0.008 & 0.06 & 7.5 & 44 & 0.5 & 0.013 & 0.046 & 0.013 & $\log$ effluent $=0.548(\log$ influent $)-0.7297$ \\
\hline Filtered copper $(\mu \mathrm{g} / \mathrm{L})$ & $7 \%$ & $57 \%$ & $<2$ & 6 & 58 & 14 & 0.4 & 0.65 (few data) & 0.030 & 0.66 & effluent $=3 \mu \mathrm{g} / \mathrm{L}(\mathrm{COV}=0.24)$ \\
\hline Filtered zinc $(\mu \mathrm{g} / \mathrm{L})$ & $0 \%$ & $44 \%$ & 3 & 27 & 70 & 25 & 0.8 & $8.60 \times 10^{-6}$ & $\mathrm{n} / \mathrm{a}$ & $5.40 \times 10^{-6}$ & $\log$ effluent $=0.467$ (log influent) \\
\hline Ammonia (mg/L) & $2 \%$ & $39 \%$ & 0.15 & 1.7 & 90 & 41 & 0.6 & 0.026 & $8.10 \times 10^{-6}$ & 0.026 & $\log$ effluent $=1.049(\log$ influent $)-1.0028$ \\
\hline Nitrate plus nitrite (mg/L) & $0 \%$ & $4 \%$ & 0.061 & 0.59 & 17 & 23 & 0.7 & 0.00898 & 0.0226 & 0.0089 & $\log$ effluent $=0.557(\log$ influent $)-0.358$ \\
\hline Chloride (mg/L) & $42 \%$ & $4 \%$ & $<1$ & 11 & -140 & 24 & 1.3 & $3.70 \times 10^{-7}$ & $n / a$ & $1.90 \times 10^{7}$ & $\log$ effluent $=1.728$ (log influent) \\
\hline Fecal coliforms (\#/100 mL) & $5 \%$ & $16 \%$ & 1 & 17000 & 71 & 19 & 2.9 & 0.00418 & 0.03 & 0.0042 & $\log$ effluent $=0.446(\log$ influent $)+0.801$ \\
\hline E. coli (\#/100 mL) & $17 \%$ & $9 \%$ & 1 & 1842 & -29 & 23 & 3.6 & 0.042 & 0.015 & 0.042 & $\log$ effluent $=0.442(\log$ influent $)+0.799$ \\
\hline Enterococci (\#/100 mL) & $0 \%$ & $0 \%$ & 4 & 4200 & 11 & 27 & 1.6 & $3.40 \times 10^{-8}$ & 0.00035 & $3.40 \times 10^{-8}$ & ${ }^{8} \log$ effluent $=0.596(\log$ influent $)+0.70$ \\
\hline
\end{tabular}


Table 7 Media capacities for filtered pollutants for biofilter media components and mixtures.

\begin{tabular}{|c|c|c|c|c|c|c|c|c|c|c|}
\hline & $\begin{array}{c}\text { GAC } \\
\text { mg pol/gm } \\
\text { media }\end{array}$ & $\begin{array}{l}\text { Peat moss } \\
\text { mg pol/gm } \\
\text { media** }^{* *}\end{array}$ & $\begin{array}{l}\text { Rhyolite sand } \\
\text { mg pol/gm } \\
\text { media }\end{array}$ & $\begin{array}{l}\text { Site sand } \\
\text { mg pol/gm } \\
\text { media }\end{array}$ & $\begin{array}{l}\text { Site zeolite } \\
\text { mg pol/gm } \\
\text { media }\end{array}$ & $\begin{array}{c}\text { SMZ } \\
\text { mg pol/gm } \\
\text { media }\end{array}$ & $\begin{array}{c}\text { R-SMZ } \\
\text { mg pol/gm } \\
\text { media }\end{array}$ & $\begin{array}{l}\text { R-SMZ-GAC } \\
\text { mg pol/gm } \\
\text { media }\end{array}$ & $\begin{array}{c}\text { R-SMZ-GAC-PM } \\
\text { mg pol/gm } \\
\text { media }\end{array}$ & $\begin{array}{c}\text { Site sand- } \\
\text { GAC-site zeolite } \\
\text { layered } \\
\mathrm{mg} \mathrm{pol} / \mathrm{gm} \\
\text { media }\end{array}$ \\
\hline Sulfate & 0.64 & -0.00001 & 0.030 & $>0.016$ & 0.067 & 0.091 & 0.047 & $>0.27$ & 0.055 & $>0.31$ \\
\hline Calcium, Filtered & 0.37 & $>6.3$ & 0.12 & 0.017 & 0.25 & 0.082 & 0.056 & 0.072 & 0.14 & 0.081 \\
\hline Chloride & 0.010 & -0.00001 & 0.00 & 0.00 & 0.00 & 0.00 & 0.00 & 0.00 & 0.0066 & 0.00 \\
\hline Sodium, Filtered & 0.033 & -0.00001 & 0.00 & 0.0079 & 0.00 & 0.024 & 0.00 & 0.00 & 0.00 & 0.00 \\
\hline Ammonia & $>0.23^{*}$ & 0.056 & $>0.12$ & $>0.00073$ & $>0.22$ & $>0.17$ & $>0.066$ & $>0.089$ & $>0.10$ & $>0.067$ \\
\hline Nitrate & $>0.52$ & 0.011 & 0.012 & $>0.0033$ & 0.0034 & 0.0087 & 0.0044 & 0.10 & 0.10 & $>0.12$ \\
\hline Nitrite & 0.00019 & 0.00 & 0.00 & 0.00 & 0.00018 & 0.00011 & 0.00 & 0.00015 & 0.00008 & 0.00028 \\
\hline Phosphate & 0.0 & -0.00001 & 0.00 & $>0.0020$ & $>0.050$ & 0.00089 & 0.00012 & 0.00 & 0.00 & 0.00 \\
\hline Boron, Filtered & $>0.011$ & 0.011 & 0.00 & 0.00025 & 0.00055 & 0.00 & 0.00071 & $>0.0036$ & $>0.0042$ & $>0.0029$ \\
\hline Cadmium, Filtered & $>0.0025$ & $>0.0089$ & $>0.0013$ & $>0.00017$ & $>0.0021$ & $>0.0016$ & $>0.00063$ & $>0.00085$ & $>0.00099$ & $>0.00068$ \\
\hline Chromium, Filtered & $>0.0012$ & $>0.0035$ & 0.00005 & 0.00001 & 0.00001 & 0.00003 & 0.00 & $>0.00036$ & $>0.00031$ & 0.00031 \\
\hline Copper, Filtered & $>0.0036$ & $>0.0082$ & 0.00019 & 0.00005 & $>0.00098$ & 0.00 & 0.00 & $>0.0011$ & $>0.00090$ & $>0.00084$ \\
\hline Iron, Filtered & $>0.0051$ & 0.00 & 0.00 & 0.00015 & 0.00 & 0.00 & 0.00 & $>0.0014$ & 0.00 & $>0.0012$ \\
\hline Magnesium, Filtered & 0.0011 & 0.0080 & 0.00 & 0.00 & $>0.092$ & 0.0 & 0.00 & 0.00 & 0.00 & 0.00000 \\
\hline Manganese, Filtered & $>0.00027$ & -0.00001 & 0.00 & 0.00 & $>0.00009$ & 0.00 & 0.00 & $>0.00009$ & 0.00 & $>0.00007$ \\
\hline Nickel, Filtered & $>0.0023$ & $>0.0078$ & $>0.0011$ & 0.00011 & $>0.0014$ & $>0.0015$ & $>0.00048$ & $>0.00065$ & $>0.00086$ & $>0.00057$ \\
\hline Thallium, Filtered & $>0.0056$ & $>0.018$ & $>0.0031$ & $>0.00033$ & $>0.0048$ & $>0.0037$ & $>0.0014$ & $>0.0019$ & $>0.0021$ & $>0.0016$ \\
\hline Zinc, Filtered & 0.00 & -0.00001 & 0.00 & 0.00 & 0.00 & 0.00 & 0.000 & 0.00 & 0.00 & $>0.00005$ \\
\hline
\end{tabular}

Table 8 Media mixture capacities for radioactive stormwater constituents.

\begin{tabular}{lcccc}
\hline & R-SMZ & R-SMZ-GAC & R-SMZ-GAC-PM & $\begin{array}{c}\text { Site sand-GAC- } \\
\text { site zeolite layered } \\
\text { pCi pol/gm media }\end{array}$ \\
\hline Gross alpha & $>0.097$ & $>0.14$ & $>0.16$ & $>0.11$ \\
Gross beta & $>0.037$ & 0.015 & 0.079 & $>0.063$ \\
Radium-226 & $>0.0041$ & 0.00 & $>0.0067$ & $>0.0047$ \\
Radium-228 & 0.00 & 0.0051 & $>0.0075$ & 0.00 \\
Alpha radium & $>0.017$ & $>0.016$ & $>0.024$ & 0.017 \\
Strontium-90 (very & 0.00 & 0.00 & 0.00 & 0.00 \\
low influent) & & & & 0.00 \\
Tritium (very low & 0.00 & 0.00 & 0.00 & 0.00 \\
influent) & $>0.024$ & $>0.035$ & $>0.041$ & 0.00 \\
Uranium & & & & \\
\hline
\end{tabular}

Table 9 Example particle size distribution of stormwater particulates.

\begin{tabular}{cc}
\hline Stormwater PSD size range $(\mu \mathrm{m})$ & $\begin{array}{c}\text { Percentage of particulates in each stormwater } \\
\text { influent PSD range }\end{array}$ \\
\hline$<3$ & 10 \\
$3-12$ & 10 \\
$13-30$ & 15 \\
$31-60$ & 25 \\
$61-150$ & 25 \\
$151-300$ & 10 \\
$301-2000$ & 5 \\
Total: & 100 \\
\hline
\end{tabular}


Table 10 Calculations to obtain media mixture PSD.

\begin{tabular}{lccccccccc}
\hline $\begin{array}{c}\text { Media size range } \\
(\mu \mathrm{m})\end{array}$ & \multicolumn{2}{c}{ Fine sand } & \multicolumn{2}{c}{ GAC } & \multicolumn{2}{c}{ Peat } & \multicolumn{4}{c}{$\begin{array}{c}\text { Weighted sum for } \\
\text { mixture }\end{array}$} & $\begin{array}{c}\text { Cumulative } \\
\text { \% in range }\end{array}$ & X0.4 & \% in range & X0.3 & \% in range & X0.3 & \% in range & Size $\mu$ m & percentage \\
\hline$<3$ & 0 & 0 & 0 & 0 & 0 & 0 & 0 & 3 & 0 \\
$3-12$ & 0 & 0 & 0 & 0 & 0 & 0 & 0 & 12 & 0 \\
$13-30$ & 0 & 0 & 0 & 0 & 1 & 0.3 & 0.3 & 30 & 0.3 \\
$31-60$ & 1 & 0.4 & 0 & 0 & 2 & 0.6 & 1 & 60 & 1.3 \\
$61-150$ & 21 & 8.4 & 0 & 0 & 12 & 3.6 & 12 & 150 & 13.3 \\
$151-300$ & 33 & 13.2 & 1 & 0.3 & 17 & 5.1 & 18.6 & 300 & 31.9 \\
$301-1000$ & 37 & 14.8 & 9 & 2.7 & 28 & 8.4 & 25.9 & 1000 & 57.8 \\
$1001-2000$ & 4 & 1.6 & 36 & 10.8 & 10 & 3 & 15.4 & 2000 & 73.2 \\
$2001-3000$ & 2 & 0.8 & 36 & 10.8 & 5 & 1.5 & 13.1 & 3000 & 86.3 \\
$3001-4000$ & 2 & 0.8 & 13 & 3.9 & 7 & 2.1 & 6.8 & 4000 & 93.1 \\
$4001-6000$ & 0 & 0 & 5 & 1.5 & 9 & 2.7 & 4.2 & 6000 & 97.3 \\
$6001-8000$ & 0 & 0 & 0 & 0 & 2 & 0.6 & 0.6 & 8000 & 97.9 \\
$>8000$ & 0 & 0 & 0 & 0 & 7 & 2.1 & 2.1 & & \\
Sum & 100 & 40 & 100 & 30 & 100 & 30 & 100 & & \\
\hline
\end{tabular}

Table 11 Particulate solids removal calculations.

\begin{tabular}{|c|c|c|c|c|c|}
\hline Stormwater size range $(\mu \mathrm{m})$ & $\begin{array}{l}\text { Fraction of material in each storm- } \\
\text { water influent size range }\end{array}$ & $\begin{array}{l}\text { Inf part solids conc. } \\
\text { Total SSC = } 300 \mathrm{mg} / \mathrm{L} ; \\
\text { conc in size range }\end{array}$ & $\begin{array}{l}\text { Effluent for intermediate media mixture (for low } \\
\text { to high SSC concentrations and intermediate sized } \\
\text { media, from on-line Appendix tables) }\end{array}$ & Effluent \% PSD & Effluent cumulative \% \\
\hline$<3$ & 10 & 30 & $30.0^{*}$ & 36.9 & 36.9 \\
\hline $3-12$ & 10 & 30 & 26.8 & 33.0 & 69.9 \\
\hline $13-30$ & 15 & 45 & 17.1 & 21.0 & 90.9 \\
\hline $31-60$ & 25 & 75 & 3.33 & 4.1 & 95.0 \\
\hline $61-150$ & 25 & 75 & 3.33 & 4.1 & 99.1 \\
\hline $151-300$ & 10 & 30 & 0.7 & 0.9 & 100.0 \\
\hline \multirow[t]{2}{*}{$301-2000$} & 5 & 15 & 0 & 0.0 & 100.0 \\
\hline & 100 & $300 \mathrm{mg} / \mathrm{L}$ & $81.3 \mathrm{mg} / \mathrm{L}$ & 100 & \\
\hline
\end{tabular}

* effluent concentration cannot be greater than influent concentration for each particle size range, except for $<3 \mu \mathrm{m}$ where increased concentrations can be associated with fines being washed from media.

Table 12 Treatment flow rate for media components.

\begin{tabular}{lc}
\hline & $\mathrm{cm} / \mathrm{h}$ \\
\hline Fine sand & 33 \\
GAC & 100 \\
Peat & use peat/sand equations \\
\hline
\end{tabular}

Table 13 Maximum sediment load before clogging for mixture.

\begin{tabular}{lccc}
\hline & $\begin{array}{c}\text { Maximum sediment load, from Table } 1 \\
\left(\mathrm{~kg} / \mathrm{m}^{2}\right)\end{array}$ & \% in mixture & Weighted capacity \\
\hline Fine sand & 10 & 40 & 4 \\
GAC & 38 (coarse material) & 30 & 11.4 \\
Peat & 20 & 30 & 6 \\
Total & & & $21.4 \mathrm{~kg} / \mathrm{m}^{2}$ \\
\hline
\end{tabular}

Table 14 Filtered pollutant removal equations for example.

\begin{tabular}{lcccc}
\hline & $\begin{array}{c}\text { Influent } \\
\text { concentration }\end{array}$ & $\begin{array}{c}\text { GAC removal } \\
\text { equation* }\end{array}$ & $\begin{array}{c}\text { Peat removal } \\
\text { equation }\end{array}$ & $\begin{array}{c}\text { Sand removal } \\
\text { equation* }\end{array}$ \\
\hline Copper (filtered), $\mu \mathrm{g} / \mathrm{L}$ & 15 & $\mathrm{Y}=6.8(0.64)$ & $\mathrm{Y}=12.3(0.26)$ & $\mathrm{Y}=\mathrm{X}$ \\
Ammonia, $\mathrm{mg} / \mathrm{L}$ & 0.9 & $\mathrm{Y}=0.27(2.1)$ & $\mathrm{Y}=\mathrm{X}$ & $\mathrm{Y}=0.54 \mathrm{X}$ \\
Nitrate, $\mathrm{mg} / \mathrm{L}$ & 20 & $\mathrm{Y}=46(0.63)$ & $\mathrm{Y}=\mathrm{X}$ & $\mathrm{Y}=\mathrm{X}$ \\
Phosphate, $\mathrm{mg} / \mathrm{L}$ & 2.3 & $\mathrm{Y}=3.7(0.62)$ & $\mathrm{Y}=\mathrm{X}$ & $\mathrm{Y}=0.48 \mathrm{X}$
\end{tabular}

*effluent median concentration and coefficient of variation, if no regression equation shown

Table 15 Filtered pollutant removal calculations.

\begin{tabular}{lcccccccc}
\hline & \multicolumn{3}{c}{$\begin{array}{c}\text { Effluent for media } \\
\text { component }\end{array}$} & \multicolumn{7}{c}{ Weighted calculation } \\
& GAC & Peat & Sand & $\begin{array}{c}\text { GAC } \times \\
0.3\end{array}$ & $\begin{array}{c}\text { Peat } \times \\
0.3\end{array}$ & $\begin{array}{c}\text { Sand } \times \\
0.4\end{array}$ & $\begin{array}{c}\text { Sum } \\
\text { (final } \\
\text { conc.) }\end{array}$ & $\begin{array}{c}\text { \% reductions } \\
\text { for filtered } \\
\text { form }\end{array}$ \\
\hline $\begin{array}{l}\text { Copper } \\
\text { (filtered) }\end{array}$ & 6.8 & 12 & 15 & 2.0 & 3.7 & 6.0 & 12 & 21.8 \\
Ammonia & 0.27 & 0.9 & 0.49 & 0.081 & 0.27 & 0.20 & 0.55 & 39.4 \\
Nitrate & 46 & 20 & 20 & 13.8 & 6.0 & 8.0 & 28 & -39.0 \\
Phosphate & 3.7 & 2.3 & 1.1 & 1.1 & 0.69 & 0.44 & 2.2 & 2.5 \\
\hline
\end{tabular}


Table 16 Effects of contact times on filtered pollutant removals for example.

\begin{tabular}{|c|c|c|c|c|c|c|}
\hline & \multicolumn{2}{|c|}{$\mathrm{GAC}$} & \multicolumn{2}{|c|}{ R-sand } & \multicolumn{2}{|r|}{ PM } \\
\hline & $\begin{array}{l}\text { Minimum time } \\
\text { (min) }\end{array}$ & $\begin{array}{c}\% / \text { min } \\
\text { (after minimum time) }\end{array}$ & $\begin{array}{c}\text { Minimum time } \\
\text { (min) }\end{array}$ & $\begin{array}{c}\% / \mathrm{min} \\
\text { (after minimum time) }\end{array}$ & $\begin{array}{c}\text { Minimum time } \\
\text { (min) }\end{array}$ & $\begin{array}{c}\% / \text { min } \\
\text { (after minimum time) }\end{array}$ \\
\hline Ammonia & 200 & 0.025 & 20 & 0.012 & 2000 & 0.017 \\
\hline Nitrate & 20 & 0.061 & $\mathrm{n} / \mathrm{a}$ & $\mathrm{n} / \mathrm{a}$ & $\mathrm{n} / \mathrm{a}$ & $\mathrm{n} / \mathrm{a}$ \\
\hline Phosphate & 1 & -0.04 & 1 & 0.006 & 1000 & 0.015 \\
\hline Copper & 1 & 0.08 & 100 & 0.044 & 1 & 0.08 \\
\hline
\end{tabular}

Table 17 Media pollutant retention capacities of example.

\begin{tabular}{lccc}
\hline & \multicolumn{3}{c}{ mg pollutant/kg media } \\
& GAC & Peat & Sand \\
\hline Copper (filtered) & 0.0036 & 0.0083 & 0.00 \\
Ammonia & 0.24 & 0.00 & 0.00073 \\
Nitrate & 0.53 & 0.00 & 0.0034 \\
Phosphate & 0.00 & 0.00 & 0.0021 \\
\hline
\end{tabular}

Table 18 Total media filtered pollutant retention capacity of example.

\begin{tabular}{lccccc}
\hline & \multicolumn{2}{c}{ Weighted capacity (fraction) } & $\begin{array}{c}\text { mg pollutant/g } \\
\text { media }\end{array}$ & $\begin{array}{c}\text { mg pollutant } \\
\text { capacity for } \\
\text { biofilter }\end{array}$ \\
& GAC 0.3 & Peat 0.3 & Sand 0.4 & Total capacity & \\
\hline Copper (filtered) & 0.0011 & 0.0025 & 0 & 0.0036 & 390000 \\
Ammonia & 0.071 & 0 & 0.00029 & 0.071 & 7900.000 \\
Nitrate & 0.16 & 0 & 0.0014 & 0.16 & 18000000 \\
Phosphate & 0 & 0 & 0.00082 & 0.00082 & 91000 \\
\hline
\end{tabular}

Table 19 Total media capacity of example.

\begin{tabular}{lccccc}
\hline \multicolumn{1}{c}{ Pollutant } & $\begin{array}{c}\text { Influent } \\
\text { concentration }\end{array}$ & $\begin{array}{c}\text { Effluent } \\
\text { concentration }\end{array}$ & $\begin{array}{c}\text { Retained } \\
\text { concentration }\end{array}$ & $\begin{array}{c}\text { Retained } \\
\text { mass }\end{array}$ & $\begin{array}{c}\text { Retained } \\
\text { mass }(\mathrm{mg})\end{array}$ \\
\hline Copper (filtered), $\mu \mathrm{g} / \mathrm{L}$ & 15 & 12 & 3.3 & $290000 \mu \mathrm{g}$ & 290 \\
Ammonia, $\mathrm{mg} / \mathrm{L}$ & 0.9 & 0.55 & 0.35 & $31000 \mathrm{mg}$ & 31000 \\
Nitrate, $\mathrm{mg} / \mathrm{L}$ & 20 & 28 & -7.8 & $\mathrm{n} / \mathrm{a}$ & $\mathrm{n} / \mathrm{a}$ \\
Phosphate, $\mathrm{mg} / \mathrm{L}$ & 2.3 & 2.2 & 0.058 & $5100 \mathrm{mg}$ & 5100 \\
\hline
\end{tabular}

Table 20 Expected run times before breakthrough.

\begin{tabular}{lccc}
\hline & Pollutant capacity for biofilter (mg) & $\begin{array}{c}\text { Fraction of total consumed by example } \\
25 \mathrm{~mm} \text { rain } \\
\text { (mg retained/mg capacity ratio) }\end{array}$ & $\begin{array}{c}\text { Approx. meters of rain before break- } \\
\text { through }\end{array}$ \\
\hline Copper (filtered) & 390000 & 0.00073 & 35 \\
Ammonia & 7900000 & 0.0039 & 6.5 \\
Nitrate & 18000000 & $\mathrm{n} / \mathrm{a}$ & $\mathrm{n} / \mathrm{a}$ \\
Phosphate & 91000 & 0.056 & 0.45 \\
\hline
\end{tabular}

